4 norden 



\section{PCB i bygg - ut av kretsløpet}


PCB i bygg - ut av kretsløpet

TemaNord 2007:516

(c) Nordisk Ministerråd, København 2007

ISBN 978-92-893-1464-0

Opplag: Print-on-Demand

Publikasjonen kan bestilles på www.norden.org/order. Flere publikasjoner på www.norden.org/publikationer

Nordisk Ministerråd

Store Strandstræde 18

1255 Copenhagen $\mathrm{K}$

Telefon (+45) 33960200

Fax (+45) 33960202

\section{Nordisk Råd}

Store Strandstræde 18

1255 Copenhagen $\mathrm{K}$

Telefon (+45) 33960400

Fax (+45) 33111870

www.norden.org

\section{Det nordiske miljøsamarbeidet}

Det nordiske miljøhandlingsprogrammet 2005-2008 utgjør rammen rundt de nordiske landenes miljøsamarbeid, både innenfor Norden og i forhold til nærområdene, Arktis, EU og øvrige internasjonale fora. Programmet legger opp til resultater som sikrer Nordens posisjon som foregangsregion på miljøområdet. En overordnet målsetting er blant annet å skape levekår som gir bedre helse for befolkningen i Norden.

\section{Det nordiske samarbeidet}

Det nordiske samarbeid er en av verdens mest omfattende regionale samarbeidsformer. Samarbeidet omfatter Danmark, Finland, Island, Norge og Sverige, samt de selvstyrende områdene Færøyene, Grønland og Åland.

Det nordiske samarbeid er både politisk, økonomisk og kulturelt forankret, og er en viktig medspiller i det europeiske og internasjonale samarbeid. Det nordiske fellesskap arbeider for et sterkt Norden i et sterkt Europa.

Det nordiske samarbeid ønsker å styrke nordiske og regionale interesser og verdier i en global omverden. Felles verdier landene imellom er med til å styrke Nordens posisjon som en av verdens mest innovative og konkurransekraftige regioner. 


\section{Innhold}

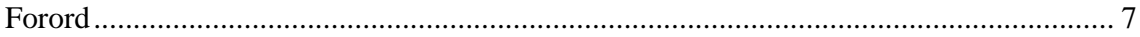

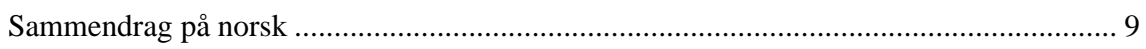

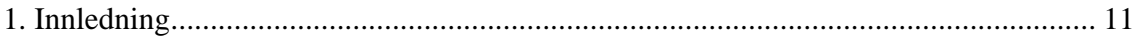

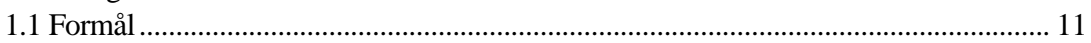

1.2 Problemdefinisjon ........................................................................................... 11

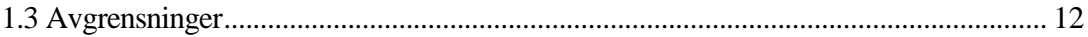

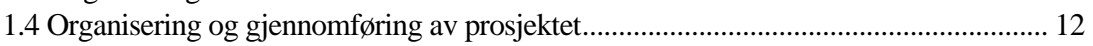

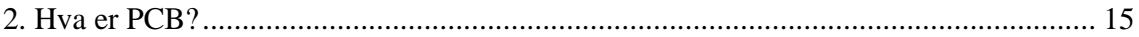

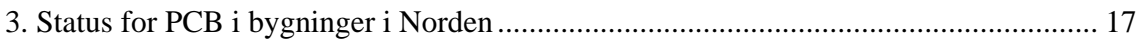

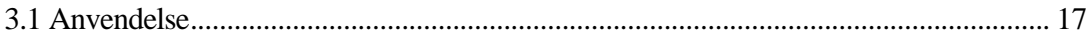

3.1.1 PCB i fugemasser ................................................................................... 18

3.1.2 Gulvmasser og gulvlim......................................................................18

3.1.3 PCB-holdig mørteltilsetning...................................................................18

3.1.4 Maling ................................................................................................. 19

3.1.5 Isolerglassruter med PCB ..................................................................19

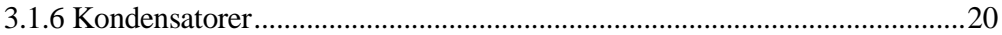

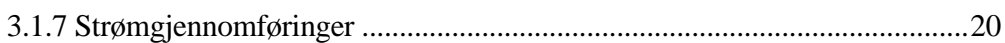

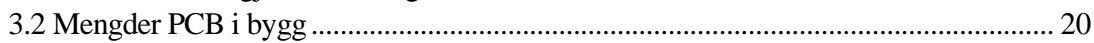

3.2.1 Opprinnelige mengder og bruk av PCB .....................................................20

3.2.2 Gjenværende mengder PCB i bygg.........................................................21

3.3 Virkemidler og tiltak for å hindre spredning av PCB ................................................... 22

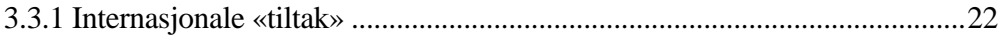

3.3.2 Nasjonale mål og strategier .........................................................................23

3.3.3 De nordiske landenes ulike arbeidsmåter.....................................................26

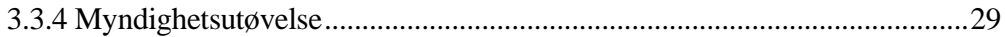

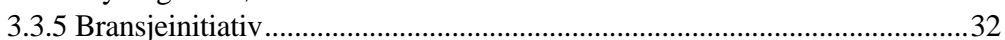

3.3.6 Standardisering / kontrollordninger...............................................................36

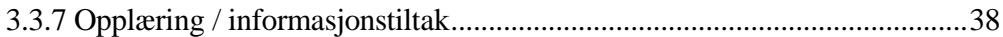

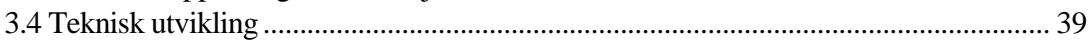

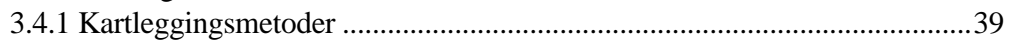

3.4.2 Kartleggings- og analysemetoder ................................................................4

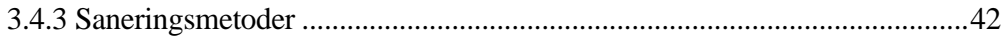

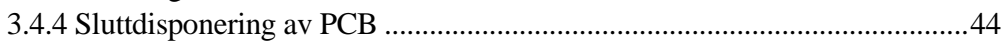

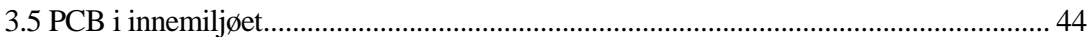

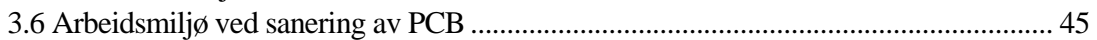

3.7 Spredning av PCB fra bygninger til omgivelsene............................................................ 46

3.8 Avfallshåndtering...................................................................................................... 48

3.8.1 Grenseverdier for PCB-holdig avfall ...........................................................48

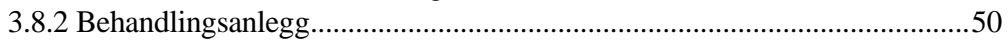

3.8.3 Gjenvinning av PCB-holdig rivemateriale..................................................50

3.8.4 Transport av PCB-holdig avfall ...................................................................51

3.9 Forskning og utvikling................................................................................................ 53

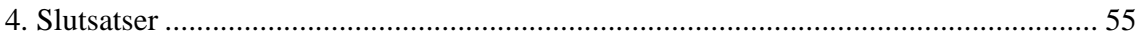

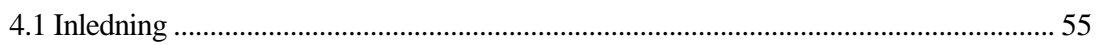

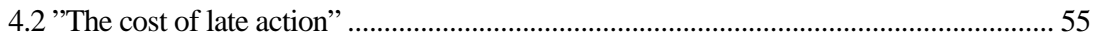

4.3 Olika perspektiv och prioriteringar i de nordiska länderna........................................... 55 
4.4 Har Norden något att lära Europa och den övriga omvärlden?........................................ 56

4.5 Det finns brister beträffande kunskap och kompetens om PCB ................................... 57

4.6 Det finns behov av bättre miljöinventeringar och bättre rivnings- och avfallsplaner.... 58

4.7 Kvaliteten på miljöinventeringarna är låg ............................................................... 58

4.8 Brister beträffande rådgivning, tillsyn och kontroll från myndigheterna......................... 58

4.9 Det finns kvalitetsbrister vid sanering av PCB .............................................................. 59

4.10 Arbetsmiljön vid sanering av PCB behöver utvecklas.................................................. 59

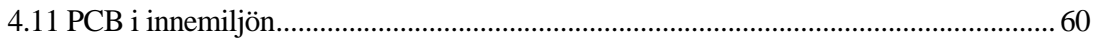

4.12 PCB i färger, putser och murade konstruktioner ............................................................. 60

4.13 Miljörisker vid återvinning av PCB-förorenade byggmaterial .......................................60

4.14 Sanering av PCB-förorenad jord ................................................................................. 61

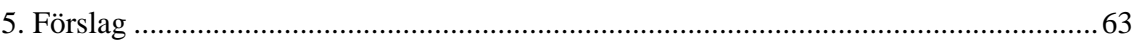

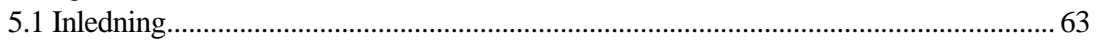

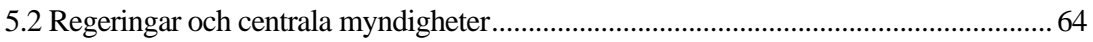

5.2.1 Gemensam nordisk syn på PCB i byggnader................................................64

5.2.2 Gemensam nordisk strategi beträffande PCB i byggnader och byggavfall. 64

5.2.3 Krav på avfallsplaner...................................................................................64

5.2.4 Viktiga arbetsuppgifter för de centrala myndigheterna .................................65

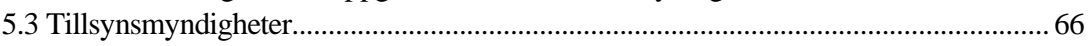

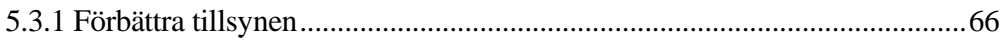

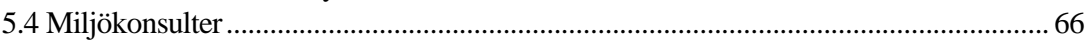

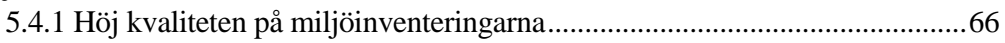

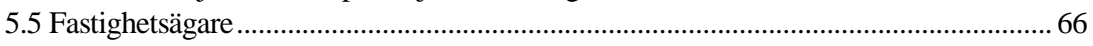

5.5.1 Kartlägg PCB och förbered för sanering.....................................................66

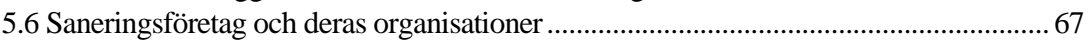

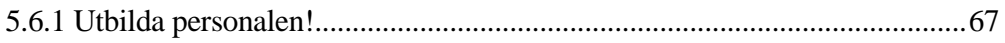

5.6.2 Kvalitetssäkra saneringsarbetet .....................................................................67

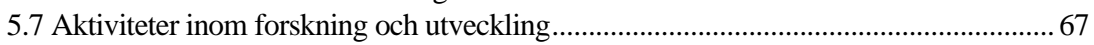

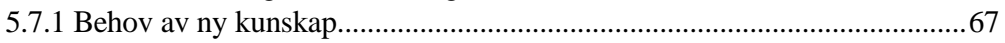

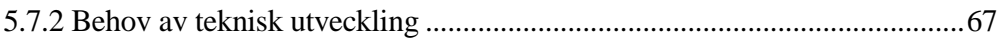

5.7.3 Samordna FoU-arbetet i de nordiska länderna............................................68

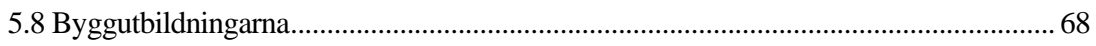

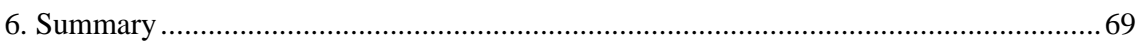

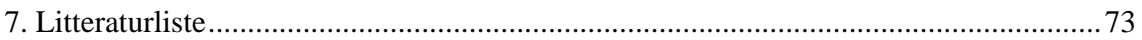

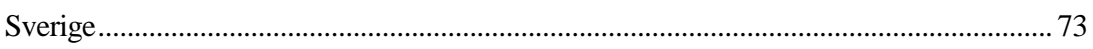

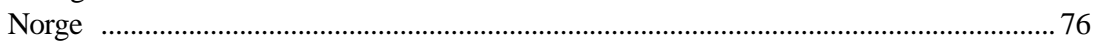

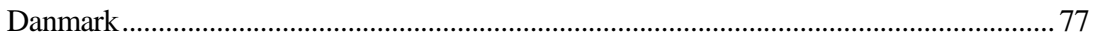

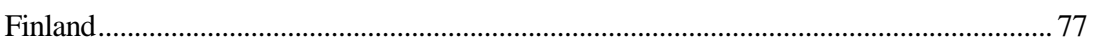

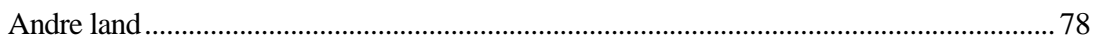

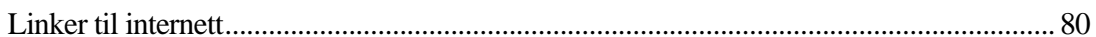




\section{Forord}

Foreliggende rapport om PCB i bygg er en av to rapporter fra seminaret «Riving og PCB i bygg» som byggenæringen i Norden arrangerte på Holmenkollen Park Hotel i Oslo 7. og 8. mars 2005. Prosjektet er støttet av Nordisk Ministerråd og rapportene inngår i serien Tema Nord. Den andre rapporten omhandler bygge- og riveavfall i Norden.

Rapportene oppsummerer det som kom fram gjennom foredragene på seminaret, innspillene og diskusjonene underveis og arbeid som er gjort av de nordiske samarbeidspartene i etterkant av seminaret.

Ideen til å gjennomføre seminaret kom etter at Byggenæringens Landsforening (BNL) hadde laget kurs i PCB-sanering i samarbeid med Fellesforbundet i Norge. Det viste seg at informasjon om sanering av PCB i bygg var vanskelig tilgjengelig internasjonalt, men at de Nordiske landene hadde gjort ulike tiltak for å avhjelpe PCB-problematikken. På seminaret på Holmekollen fikk vi effektivt samlet ekspertene på PCB i bygg i Norden til felles informasjonsutveksling. Vi håper rapportene vil være til nytte for byggenæring, myndigheter, universiteter, institutter og andre i de nordiske landene.

BNL har vært initiativtaker og prosjektansvarlig for seminaret og rapportene. Vi vil gjerne takke våre samarbeidsparter i Kretsloppsrådet $\mathrm{i}$ Sverige, Tekniska Universitetet i Tampere i Finland, Dansk Byggeri i Danmark og Umhverfis- og heilbrigðisstofa Reykjavíkur, Island for godt samarbeid. Til sist vil vi takke vår prosjektleder Bjørn Smits fra AF Decom AS og Per Lilliehorn fra Kretsloppsrådet som har bidratt sterkt til rapporteringen. Smits har vært både faglig og administrativ leder av prosjektet.

Det nordiske samarbeidet preger rapporten også språklig. Vi håper våre lesere vil bære over med at vi har brukt flere av de nordiske språkene i rapporten. I ettertid ser vi at det ville ha vært nyttig å ha en engelsk oversettelse av hele rapporten; ikke bare sammendraget.

Takk til Nordisk Ministerråd for godt samarbeid og økonomisk støtte.

\section{Rannveig Ravnanger Landet}

Byggenæringens Landsforening, BNL

Prosjektansvarlig 



\section{Sammendrag på norsk}

PCB i bygninger er et problem i alle land, dog i noe varierende omfang og typer av forekomster. PCB er en miljøgift som akkumuleres i næringskjeden og skaper potensiell helsefare både for mennesker og dyr. PCB ble benyttet i en rekke materialer og tekniske installasjoner i bygninger omtrent fra 1950-tallet frem til 1980. Mange av disse bygningene eller installasjonene er i dag modne for riving eller utskiftning. PCB i bygninger kan finnes i fugemasser, gulvemasser, maling, mørtel, isolerglassruter, kondensatorer i lysrørarmaturer, andre småkondensatorer og strømgjennomføringer i elkraft-anlegg.

De nordiske landene har arbeidet i ulik grad og på ulik måte med PCB-problematikken. Sverige har hatt høy fokus på fuger og at disse skal kartlegges og fjernes innen en gitt tidsfrist. I Sverige er anvisninger utarbeidet for inventering og sanering av fugemasser. Norge har hatt høy fokus på isolerglassruter og kondensatorer i lysrørarmaturer og har etablert returordninger som finansieres gjennom kjøp av nye produkter. I Norge kartlegger man også PCB i maling og mørtel og har utarbeidet anvisninger for sanering av slike forekomster. Finland har i likhet med Sverige hatt mest fokus på fuger, men etter hvert også maling. Danmark har til nå hatt størst fokus på størst mulig gjenvinning av bygg- og anleggsavfallet og ikke så mye på de farlige stoffene i avfallet. Island har bortsett fra tekniske installasjoner som inneholder PCB-holdig olje, ikke hatt fokus på PCB i bygninger. Felles for Norge og Sverige er at arbeidsmiljø ved sanering av PCB har hatt høy fokus. I Norge, Sverige og Finland er også studier utført med hensyn til spredning av PCB til jorden rundt bygninger.

Prosjektet Riving og PCB i bygg er et felles nordisk prosjekt. Gjennom samarbeid på tvers av de nordiske land er det oppnådd en verdifull deling av kunnskaper. Prosjektet har hatt til hensikt å være løsningsorientert og resultatene skal være gjennomførbare forslag til myndighetene og byggenæringen i de nordiske land.

Seminaret og den etterfølgende dialog mellom landene under utarbeidelse av rapporten har resultert $\mathrm{i}$ en rekke forslag til fortsatt arbeid med PCB i bygninger. Rapportens forfattere har valgt å rette forslagene til PCB-problemets ulike aktører.

Regjeringer og sentrale myndigheter

- Utforme en felles nordisk forståelse om PCB i bygninger - både som et miljø- og et helseproblem.

- Utforme en felles nordisk strategi for PCB i bygninger og rivningsavfall - at PCB skal saneres ved riving og rehabilitering. 
Dette kan i praksis innebære:

- Krav til avfallsplaner ved riving og rehabilitering.

- Felles nordisk tolkning av EUs direktiv om PCB.

- Tilpassing av regelverket gjennom tydelige retningslinjer for kartlegging, håndtering og kontroll av sanering og håndtering av PCBavfall, utformet slik at de kan forstås og anvendes i så vel store som små prosjekter.

- Felles veiledninger for tilsynsmyndighetene (om regelverk, saksbehandling og gjennomføring av tilsyn).

- Information om PCB f.eks. gjennom en felles webside der hvert land løpende kan legge inn informasjon.

- Gjentakende nordiske seminarer og faglig samarbeide

Tilsynsmyndigheter

- Forbedre tilsynet - kompetanse og ressurser er en forutsetning.

Konsulenter/rådgivere

- Forbedre kvaliteten på miljøkartlegging, f.eks. gjennom autorisering/sertifisering av miljøkartleggere.

Byggherrer

- Kartlegge PCB, planlegge før sanering og gjennomføre sanering.

- Stille kompetansekrav til miljøkartleggere og saneringsforetak.

Saneringsforetak og deres organisasjoner

- Utdanne personellet

- Kvalitetssikre arbeidet

- Autorisering eller sertifisering av saneringspersonell

Virksomheter innen forskning og utvikling

- Samordne FoU i de nordiske landene.

- FoU som øker kunnskapene om helse- og miljøpåvirkninger av, spredning av PCB og økt kartlegging av hvordan PCB ble anvendt i bygninger.

- Teknisk utvikling vedrørende saneringsutrustning, ergonomisk bedre arbeidsmetoder for fugesanering, metoder for sanering av maling, mørtel og forurenset jord.

Utdanningsinstitusjoner innen byggfag

- Skaffe kunnskap om PCB

- Formidle kunnskap om PCB ved utdanning

For alle aktørene er den viktigste prioritering man kan gjøre å sørge for at PCB blir kartlagt slik at den ikke havner ukontrollert i naturen, men kan bli sanert og håndtert på en forsvarlig måte. 


\section{Innledning}

\subsection{Formål}

Denne rapporten er et resultat av det nordiske prosjektet Riving og PCB $i$ bygg og er en av to rapporter som er et resultat av seminaret. Den andre rapporten omhandler bygge- og riveavfall i Norden.

Prosjektets hovedformål har vært å gjøre opp status for håndteringen av bygge- og riveavfall (først og fremst riveavfall) og helse- og miljøskadelige stoffer i bygg i de nordiske land, identifisere felles utfordringer samt dele kunnskaper og erfaringer.

En av de farligste miljøgiftene polyklorerte bifenyler (PCB) har hatt hovedfokus under seminaret og i prosjektet som helhet. Målet med denne rapporten er å identifisere felles utfordringer og foreslå praktiske og effektive virkemidler og tiltak som fremmer en helse- og miljømessig riktig håndtering av PCB i bygg.

Gjennom samarbeid på tvers av de nordiske land er det oppnådd en verdifull deling av kunnskaper. Prosjektet har hatt til hensikt å være bransjerettet og resultatene skal være praktisk anvendbare innenfor byggenæringen i de nordiske land.

\subsection{Problemdefinisjon}

PCB i bygninger er et problem i alle land, dog i noe varierende omfang og typer av forekomster. PCB er en miljøgift som akkumuleres i næringskjeden og skaper potensiell helsefare både for mennesker og dyr.

PCB ble mye benyttet i bygg og anlegg i perioden 1960-1980. Mange av disse byggene eller anleggene er i dag modne for rehabilitering eller riving. Hver dag deponeres store mengder PCB på avfallsdeponier eller på andre ukontrollerte plasser og på slikt vis har PCB ukontrollert blitt spredt i naturmiljøet. Vel ute i miljøet spres PCB videre og havner etter hvert i den maten vi spiser. Tiden er derfor knapp for å sette inn tiltak som sikrer at PCB blir kartlagt, sanert og forsvarlig håndtert.

De nordiske land har i ulik grad arbeidet hver for seg med forskning og tiltak for å sanere og håndtere PCB i bygg. Det er behov for å lære av hverandre og utveksle kunnskaper og erfaringer. 


\subsection{Avgrensninger}

Som det fremgår av kapittel 3.2.1 i denne rapporten er omfanget av PCB brukt i samfunnet omfattende. Det har derfor vært nødvendig å avgrense de områder prosjektet og denne rapporten skulle omfatte til PCB i bygningsmaterialer og installasjoner i bygninger på land og forurensninger fra disse.

Følgende områder er derfor ikke omhandlet i denne rapporten:

- Elkraft/høyspenning og el-distribusjon

- Industriell bruk, som f.eks. prosessanlegg, maskiner, fartøy o.l.

- Offshoreinstallasjoner

Bygninger kan imidlertid være forurenset av PCB som en følge av de virksomheter som er nevnt ovenfor og dette er da en problemstilling som rapporten omhandler, eksempelvis forurensede bygningsmaterialer som følge av lekkasje av PCB-holdig olje fra en transformator.

\subsection{Organisering og gjennomføring av prosjektet}

Prosjektet er initiert av Byggenæringens landsforening (BNL) og finansiert ved $42 \%$ prosjektmidler fra Nordisk Ministerråd og $58 \%$ egeninnsats fra prosjektdeltakerne. Gjennom etablering av et kontaktnettverk i alle de nordiske land ble det etablert en styringsgruppe og engasjert en prosjektleder.

Deltakere i styringsgruppen for prosjektet har vært følgende:

- Rannveig Ravnanger Landet, Byggenæringens Landsforening (BNL), Norge

- Per Lilliehorn, Kretsloppsrådet, Sverige

- Matti Haukijärvi, Tekniska Universitetet i Tampere, Finland

- Henrik Sørensen, Dansk Byggeri, Danmark

- Lúðvík Gústafsson, Umhverfissvið Reykjavíkurborgar, Island

Prosjektleder og sekretær for styringsgruppen har vært:

- Bjørn Smits, AF Decom AS

Prosjektet har hatt tre hovedfaser:

- Planlegging

- Seminar

- Rapportering 
I planleggingsfasen ble det arrangert et planleggingsmøte i Oslo der representanter for de ulike landene fikk komme med sine synspunkter på innhold og gjennomføring av prosjektet.

7.-8. mars 2005 ble det arrangert et seminar med 50 deltakere på Holmenkollen Park Hotell i Oslo. Seminarets første dag omhandlet presentasjoner av status for bygge- og riveavfall i Norden, mens andre dag spesielt PCB i bygg.

På grunnlag av seminaret og en faktagranskning er det blitt utarbeidet to rapporter:

- TemaNord 2007:515 Bygg- och rivningsavfall i Norden.

- TemaNord 2007:516 PCB i bygg - ut av kretsløpet.

Rapportene er utarbeidet av Bjørn Smits og Per Lilliehorn, med skriftlige bidrag fra de øvrige prosjektdeltakerne samt Niels Trap i Golder Associates og Gunilla Rex, Rex Hus \& Miljökonsult. 



\section{Hva er PCB?}

PCB er en fellesbetegnelse på klorerte bifenyler (fra engelsk polychlorinated biphenyls). Bifenyler betegner to seksringformete molekyler som henger sammen. Kloratomer kan teoretisk finnes i til sammen 209 forskjellige kombinasjoner på disse, slik at man snakker om 209 forskjellige såkalte kongener. Teknisk PCB består i praksis av en blanding av et mindre antall kongener (knapt 150 kongener har blitt gjenfunnet i tekniske produkter). PCB har bl.a. god isoleringsevne (verdifulle egenskaper i elektriske apparater), er brannhemmende og har blitt benyttet som mykgjørere og bindemiddel i fugemasse, murverk og maling.

PCB-ene er giftige, men ikke akutt toksiske. Et særtrekk ved PCB-ene er at de er meget stabile. De har dermed lang oppholdstid i miljøet og spres vidt. PCB-ene bioakkumuleres, hvilket betyr at de lagres upp i levende vev slik at innholdet der blir høyere enn i omgivelsene. Ettersom de også biomagnifiseres, så finner man mer PCB høyere opp i næringskjedene. Det innebærer risiko både for menneskenes helse og for vårt miljø.

Over tid kan selv meget lave inntak gi alvorlige helseskader, blant annet skader på immun- og nervesystem og på reproduksjonssystemet. Til og med påvirkning i forløpet av kreftsykdommer kan settes i sammenheng med forhøyede PCB-verdier. Eksponering i mors liv kan gi utviklings- og atferdsforstyrrelser.

Liten nedbrytbarhet og svært høy giftighet er en meget uheldig kombinasjon som etter hvert har ført til strenge tiltak. Bruken av PCB er nå forbudt, men PCB spres fortsatt i miljøet fra produkter og sterkt forurensede områder. Eksponering skjer dermed likevel, særlig via næringsmidler som fet fisk, eller fiskelever. Det er derfor i flere land utarbeidet kostholdsråd for næringsmidler fra forskjellige forurensede sjøer, fjord- og havneområder. Arbeidsmiljøet kan også være en viktig kilde til PCBeksponering, dersom ikke sikkerhetstiltakene ved sanering er tilstrekkelige. Det er derfor all grunn til å beskytte både seg selv, andre og naturen mot PCB. 



\section{Status for PCB i bygninger i Norden}

\subsection{Anvendelse}

PCB ble benyttet $\mathrm{i}$ en rekke materialer og tekniske installasjoner i bygninger omtrent fra 1950-tallet frem til 1980. Størst omfang av bruk har vært på 1960 og -70 tallet. Bruksformål og omfang har vært forskjellig i de nordiske land. I Tabell 1 er det gitt en oversikt over kjente forekomster av PCB i bygninger i de ulike land.

Tabell 1. Anvendelse av PCB i de nordiske land.

\begin{tabular}{|c|c|c|c|c|c|c|c|c|}
\hline & 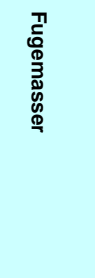 & 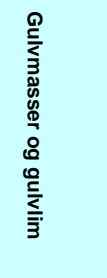 & 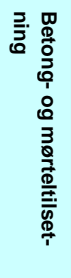 & 晃 & 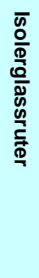 & 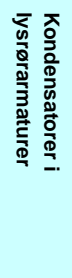 & 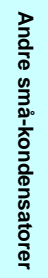 & 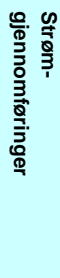 \\
\hline SE & & $\begin{array}{l}\text { Acry- } \\
\text { dur-gulv }\end{array}$ & & & & & & \\
\hline 듬ㄴ & & & & & & & & \\
\hline DK & & & & & & & & \\
\hline FIN & & & & & & & & \\
\hline & $\begin{array}{l}\text { Ved } \\
\text { vinduer }\end{array}$ & & & & & & & \\
\hline
\end{tabular}

Forekommer

Forekommer i stort omfang (mer enn 50 tonn)

Usikkert om det forekommer eller ikke 
Som det fremkommer av Tabell 1 er det usikkert om PCB finnes i murverk/ gulvmasser, maling og strømgjennomføringer i flere land, mens fugemasser, isolerglassruter og kondensatorer forekommer i alle land, vel og merke i varierende omfang.

\subsubsection{PCB i fugemasser}

Bruken av fugemasser er sterkt varierende i de nordiske land. Dette kommer særlig av byggemåte og i hvilke tidsperioder større bygninger er oppført. Sverige og Finland er i en særstilling med hensyn til bruk av fugemasser. Beskrivelsen nedenfor er først og fremst relatert til den svenske situasjonen.

På 1950- og 1960-tallet var polysulfidgummi den viktigste råvaren for elastiske fugemasser. I en del av disse ble PCB anvendt som mykgjørende komponent, i blant i kombinasjon med andre mykgjørere. På 1960- og 1970-tallet ble det utviklet nye typer av elastiske fugemasser i første omgang av typen polyuretan- og silikonfugemasser. I disse ble det ikke anvendt PCB. Bare polysulfidfugemassene har altså fra begynnelsen en tilsetning av PCB. PCB-innholdet i polysulfidfugemasser har vært ca 520 vektprosent. Den dominerende anvendelsen av polysulfidfugemassene i Sverige var til utvendig tetting av bevegelsesfuger m.m. Man finner derfor først og fremst PCB-holdige fugemasser mellom fasadeelement, i bevegelsessfuger (i fasader, gulvdekker m.m.) og i utvendige tilslutningsfuger ved vinduer, dører og lignende. Ikke bare betongelement, men også fasadeplater av f.eks. naturstein kan være fugede med PCB-holdige fugemasser. De kan også sjelden forekomme innomhus som fugetetting i for eksempel entréer og trappehus.

\subsubsection{Gulvmasser og gulvlim}

I Sverige har PCB blitt anvendt i plastbaserte gulvmasser av fabrikatet Acrydur, et sklisikkert og solid gulvbelegg som har blitt anvendt først og fremst innen industrien, for eksempel i storkjøkken og næringsmiddelindustri. Slik anvendelse er ikke kjent i de øvrige nordiske land. Bindemiddelet i gulvbelegget inneholdt ca 20 vektprosent PCB og i det ferdige gulvbelegget var innholdet ca 12 vektprosent PCB.

Det finnes også rapporter om att PCB skal blitt anvendt i gulvlim, men det er usikkert i hvilket omfang det kan ha forekommet. PCB har trolig blitt anvendt på denne måten i alle de nordiske land.

\subsubsection{PCB-holdig mørteltilsetning}

I Norge kan murpuss, avrettingsmasse og betonglim inneholde PCB. PCB-holdig mørteltilsetning blant annet av typen Borvibet ble solgt på litersbokser og brukt utendørs og innendørs i bygninger i perioden 1960- 
72. Produktet ble blant annet anvendt til sårutbedring i murpuss, betong og annet murverk, i puss på betong o.l., for flissetting og fuging, for avretting for gulvbelegg og som slitelag på gulv. Det er ikke kjent om slik anvendelse av PCB forekommer i andre land enn Norge. Materialer med PCB-holdig mørteltilsetning vil som oftest (i de tilfeller man kjenner til) inneholde PCB i konsentrasjoner under $50 \mathrm{mg} / \mathrm{kg}$, men kan i enkelte tilfeller der det er benyttet mye mørteltilsetning (gjerne påsmurt i lag for å sikre bedre vedheft) inneholde høyere konsentrasjoner. Slik situasjonen er i Norge, fordeler den PCB-holdige mørteltilsetningen seg over svært store volumer mørtel/murverk.

\subsubsection{Maling}

Forskjellige typer av eldre maling kan inneholde PCB. Omfanget i bruk av slik maling i Norden er ikke godt nok kjent.

I Norge finnes de høyere konsentrasjonene av PCB først og fremst i klorkautsjukmaling utendørs på betongvegger og mur, rørkonstruksjoner og innendørs i fjøs/uthus og produksjonsrom i næringsmiddelindustrien. Analyseresultater fra miljøkartlegginger de siste 5 årene viser imidlertid at PCB kan forekomme i maling i nesten alle typer bygninger både utvendig og innvendig. Norske undersøkelser viser at PCB-konsentrasjonen i maling på/i bygninger som regel ligger innenfor et variasjonsområde på 0,05-500 mg/kg og ofte svært lave konsentrasjoner, men over store arealer. I likhet med der man har PCB-holdige fugemasser vil også tilgrensende materialer kunne inneholde PCB, men i betydelig lavere konsentrasjoner enn i malingslaget.

I Finland viser nyere forskning at PCB-holdig maling særlig er anvendt innendørs på gulv og vegger (prof. Tuula Tuhkanen / TUT). PCBholdig maling er i svært liten grad anvendt utomhus på betong eller murpuss i Finland.

\subsubsection{Isolerglassruter med $P C B$}

Bruken av PCB-holdige isolerglassruter har vært forskjellig i de nordiske land. Mens de for eksempel i Norge er anvendt i alle typer bygninger, er de i Sverige først og fremst anvendt i offentlige bygninger, kontorbygninger og i liten grad i bolighus.

PCB kan forekomme i isolerglassruter i alle de nordiske land, i varierende grad og i varierende tidsepoker innenfor perioden 1950-1980. I de fleste land sluttet anvendelsen av PCB mot midten av 1970-tallet, mens det i importerte isolerglassruter kan ha blitt anvendt PCB frem til 1980.

Isolerglassene består av to glassruter med en distanseprofil og en forsegling. Det er limet som ble anvendt til å forsegle isolerglassrutene som kan inneholde PCB. Mengden anslås til 50-70 gram PCB pr kvm vindus- 
flate. Trerammer og karmer som omslutter PCB-holdige isolerglass er som regel «smittet» fordi PCB «vandrer» til omkringliggende materialer.

I Sverige er finnes opplysninger om at forseglingslim til isolerglassruter ble importert ferdigblandet og inneholdt ca 23 vektprosent PCB (Tommy Hammar, 1992).

\subsubsection{Kondensatorer}

Når det gjelder kondensatorer er forholdene temmelig like i de nordiske landene. PCB-kondensatorer ble anvendt i lysarmaturer fra cirka 1965 til og med 1979. Selv om det finnes eksempler på at lysarmaturer som er produsert senere også kan inneholde PCB, vil hovedmengden ligge innenfor dette tidsrommet. Med lysarmaturer menes lysrørarmaturer, lysreklame og kvikksølvdamplampearmaturer. En PCB-holdig kondensator i lysarmatur kan ofte inneholde 50-70 gram PCB-holdig olje.

Andre småkondensatorer som veier 100-400 gram ble anvendt i elektrisk utrustning for motorstart, for kompensering av reaktiv effekt m.m. De fantes som startkondensatorer i enfasemotorer i f.eks. vifter til oljebrennere, sirkulasjonspumper, vaskemaskiner, sentrifuger, tørketromler og kjøkkenvifter.

\subsubsection{Strømgjennomføringer}

Det er ikke kjent om slik anvendelse av PCB forekommer i andre land enn Norge. En strømgjennomføring fører strøm ut og inn av transformatorer eller gjennom veggmateriale i kraftstasjoner og lignende anlegg. Ofte kan dette være fra luftledning og gjennom betongvegg. Strømgjennomføringene er typisk ganske store, ca. 0,5 til 1,5 meter lange, og med utvendige kjøleribber. Gjennomføringene kan inneholde mange liter PCB-holdig olje. I Norge er det nedlagt forbud mot å ha PCB-holdige strømgjennomføringer i drift etter 1. januar 2010.

\subsection{Mengder PCB i bygg}

\subsubsection{Opprinnelige mengder og bruk av PCB}

Produksjon av PCB i industriell skala startet i USA i 1929. De viktigste produsentene av PCB var de store amerikanske og tyske kjemikonsernene som f.eks. Monsanto og Bayer. Man regner med at den samlede verdensproduksjonen av PCB har har vært opptil ca 1,35 Mton hvorav ca 0,5 Mton antas å ha forurenset miljøet. Den storskala anvendelse av PCB i bygninger begynte midt på 1950-tallet og pågikk inntil 1972 (1972 i Sverige, noe senere i de øvrige nordiske land) da fri anvendelse av PCB ble 
forbudt. I spesielle elektroniske tilfeller har PCB blitt anvendt helt inn i 1990-tallet.

Miljøeffektene ble oppdaget i 1966 av den danske kjemikeren Søren Jensen. Jensen kunne påvise spor av PCB i prøvemateriale fra ulike dyrearter helt tilbake til 1942.

Den dominerende anvendelsen av PCB har vært innen elkraftsektoren - el-distribusjon, jernbanenett og innen industrien. I de nordiske land har myndighetene i hovedsak fokusert på elkraftsektoren. Dette blant annet fordi de største volumene har blitt anvendt innen denne sektoren og sannsynligheten for spredning av PCB i miljøet har blitt vurdert å være størst her. Risikoen for at f.eks. transformatoroljer skulle bli anvendt som brensel i fyringsanlegg har vært særlig stor.

\subsubsection{Gjenvaerende mengder PCB i bygg}

Å kartlegge hvilke mengder PCB som er benyttet og hvilke mengder som er gjenværende er et omfattende arbeide. En slik kartlegging er utført i Norge og i Sverige. Mengdene som fremkommer i tabell 2 er å betrakte som grove anslag, siden det er en rekke usikkerheter knyttet både til kildene og til bruken av PCB i bygg.

Tabell 2. Gjenværende mengde PCB i bygninger pr 2005. Anslåtte mengder i tonn.

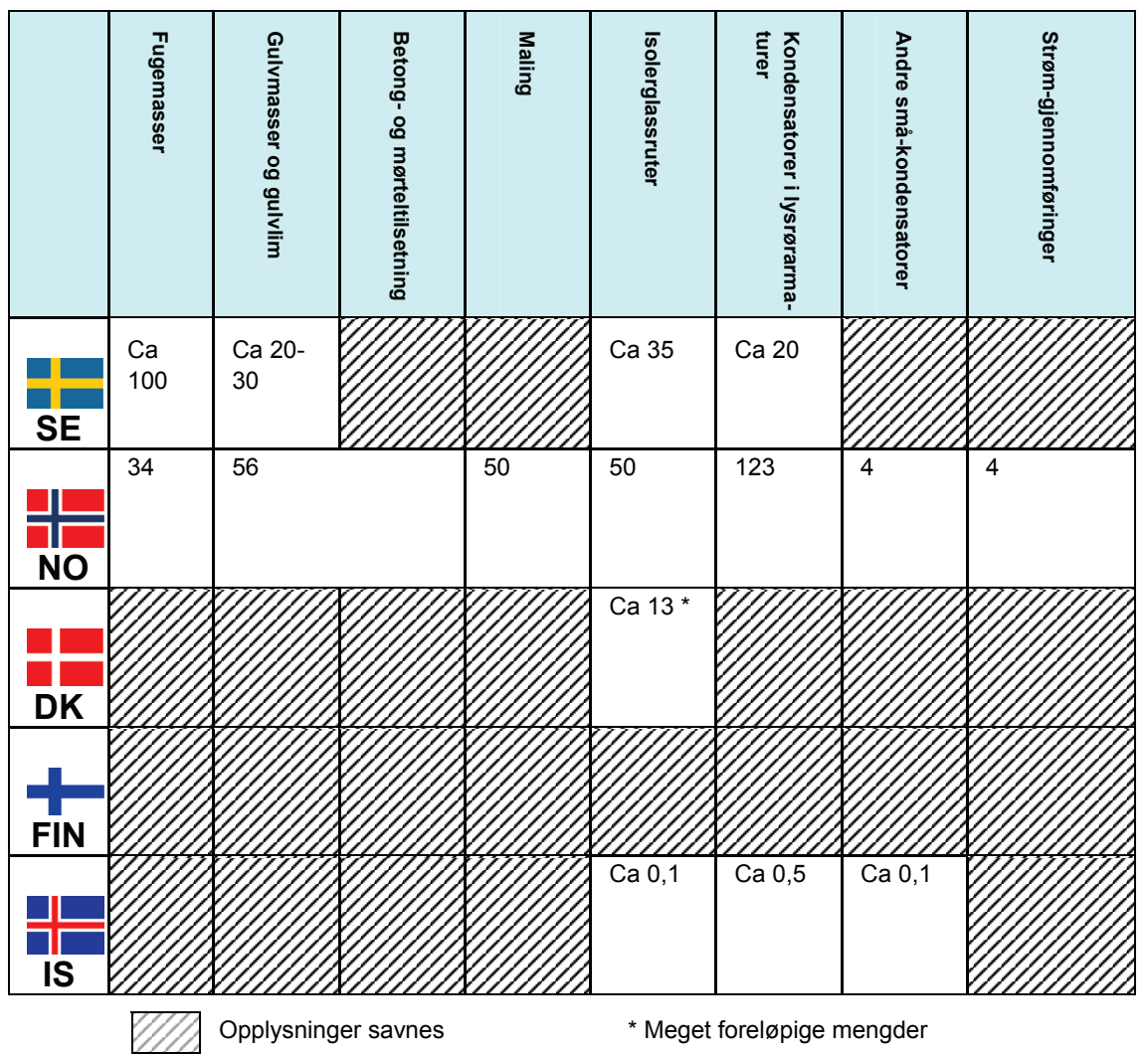


Tar vi utgangspunkt i de anslåtte mengdene og foreløpig kjennskap til forekomster i de ulike land, kan de totale mengder gjenværende PBC i nordiske bygg godt tenkes å være i størrelsesorden 1000 tonn. Dette tallet gir som sagt ikke noe eksakt estimat, men en forestilling om størrelsesorden.

Svenska opplysninger fra 1994 er hentet fra Öberg, KemI PM nr 18/94, Förekomst av PCB och PCN i varor och kemiska produkter i Sverige. Ingen nyere opplysninger er kjent i dette tilfellet.

I Norge har mengdene avtatt særlig for de forekomstene der det har vært intensivert sanering og innsamling, først og fremst isolerglassruter og kondensatorer i lysrørarmaturer.

I Danmark er den samlede resterende mengde i 2001 vurdert å utgjøre ca 60 tonn. Mengden vurderes å avta til under 10 tonn i $2010^{64}$ ved at det tas initiativ til kartlegging og innsamling av PCB-holdig avfall. PCB i bygg- og anleggsavfallet $\mathrm{i}$ kommende år vil hovedsakelig være isolerglassruter og fugemasser. Mengden PCB i isolerglassruter vurderes å utgjøre ca 13 tonn, ref. undersøkelse utført af SBI 2005, Lars Gunnarsen.

I Finland er mengdene brukt eller gjenværende PCB ukjent. Det er kjent at det ble anvendt mye i fugemasser. Flesteparten av fugene antas å være omfuget minst én gang.

På Island ble ca 100 tonn PCB-holdig transformatorolje kartlagt og samlet inn fra transformatorstasjoner i løpet av 1990-årene. Oljen ble eksportert for sluttbehandling.

\subsection{Virkemidler og tiltak for å hindre spredning av PCB}

\subsubsection{Internasjonale «tiltak»}

Stockholmskonvensjonen 2001

Gjennom den den globale Stockholmskonvensjonen forpliktet partene seg til:

- Partene forplikter seg til å eliminere/begrense utslipp av langlivede organiske forbindelser (POPs) til miljøet.

- Tolv av de aller farligste stoffene (bl.a. PCB) - «the dirty dozen» forbys eller begrenses.

- Nasjonale program for begrensning eller eliminering av utslipp av POPs.

- Program skal finnes senest to år etter at konvensjonen har trådt i kraft.

Konvensjonen trådte i kraft i mai 2004 og er implementert i EU som et direktiv. 


\section{Nordsjødeklarasjonen/OSPAR}

OSPAR er en konvensjon for beskyttelse av det marine miljø det nordøstlige Atlanterhav. Innenfor samarbeidet mellom landene som grenser til det nord-østlige Atlanterhav, arbeides det med å avklare hvilke kjemikalier som faller inn under det vedtatte målet om å stanse utslippene innen en generasjon. PCB er et av de prioriterte kjemikaliene der utslippene skal reduseres vesentlig og søkes stanset.

Mer om konvensjonen og om direktiv innen EU som regulerer håndtering og avvikling av PCB finnes i det svenske Naturvårdsverkets og Boverkets rapport, Omhändertagande av PCB i byggnader, Redovisning av ett regeringsuppdrag, juni $2002^{27}$.

Annet

- EU: nasjonalt rapporteringskrav, 2010 angående utfasing av PCB.

- Krav om utfasing av PCB finnes også i Helsingforskonvensjonen (HELCOM) som omhandler beskyttelse av Østersjøen.

- ECE-protokoll (POPs / persistente organiske miljøgifter) Economic Commission for Europa. Produksjon og ny bruk av PCB er forbudt internasjonalt gjennom ECE-protokollene.

- PIC-konvensjonen (Rotterdamkonvensjonen) omhandler informasjonsutveksling ved handel med særlig farlige stoffer. PICkonvensjonen innebærer at det etableres et informasjonsutvekslingssystem for kjemikalier som er forbudt eller strengt regulert i enkelte land. Myndigheter i mottakerlandet må informeres før visse stoffer kan føres inn i landet.

- Innen EU gjelder en forordning om grensekryssende transporter av avfall, 259:93.

\subsubsection{Nasjonale mål og strategier}

Som en oppfølging av de internasjonale avtaler har de fleste land sine nasjonale mål og strategier for PCB. 
Tabell 3. Nasjonale mål og strategier for kontroll med PCB i bygg.

\begin{tabular}{|c|l|}
\hline & \\
\hline SE & $\begin{array}{l}\text { Naturvårdsverkets og Boverkets rapport med forslag till krav om PCB-kartlegging og sane- } \\
\text { ring: Omhändertagande av PCB i bygnader, juni 2002. } \\
\text { Forordning basert på denne rapporten, med krav om kartlegging og sanering av fugemas- } \\
\text { ser (og evt. annet), forventes i løpet av 2006. }\end{array}$ \\
\hline $\mathbf{N O}$ & $\begin{array}{l}\text { Stortingsmelding nr } 58 \text { (1996-1997) inneholder Prioritetslisten som sier at PCB er et av de } \\
\text { kjemikalier som skal søkes stanset innen 2005 } \\
\text { Stortingsmelding nr 25 (2002-2003) inneholder en handlingsplan for å redusere utslipp av } \\
\text { PCB (se avsnitt nedenfor) } \\
\text { Nasjonal handlingsplan for bygg- og anleggsavfall (byggebransjen) inneholder målsetninger } \\
\text { om etablering av en returordning for isolerglassruter, kartlegging av PCB i fuger, mørtel og } \\
\text { maling og utarbeidelse av veiledningsmateriell for sanering av PCB. }\end{array}$ \\
\hline DK & $\begin{array}{l}\text { Miljøstyrelsens avfallsstrategi 2005-2008 0171«Det skal vurderes, om det oppstår helse- } \\
\text { messige effekter i forbindelse med bruk, rehabilitering og riving av bygninger som indehol- } \\
\text { der PCB» }\end{array}$ \\
\hline FIN & $\begin{array}{l}\text { Regelverk om avhending av PCB-holdige installsjoner (1998) } \\
\text { Miljöministeriets anbefalinger om tiltak ved fasaderehabiliteringer og PCB-problem (2000) } \\
\text { Arbeidsmiljømyndighetenes egne instruksjoner om trygg rehabilitering av PCB-holdige fuger } \\
\text { (slutten av 1990-tallet) }\end{array}$ \\
\hline IS & Ingen særskilte mål eller strategier vedrørende PCB i bygninger. \\
\hline IS & \\
\hline
\end{tabular}

Svenske mål og strategier

Sverige innførte allerede i 1972 et forbud mot fri anvendelse av PCB. Den svenske strategien ble senere rettet mot den store industrielle anvendelsen av PCB. Liten oppmerksomhet ble innledningsvis rettet mot anvendelsen av PCB i bygninger.

Den nåværende svenske strategien baseres på de nasjonale miljømålene. Det finnes to overgripende miljømål som vedrører PCB. Det ene miljømålet omhandler «Giftfri miljö» og med delmålene «Utfasning av särskilt farliga ämnen» og «Förorenade områden». Det andre miljømålet omhandler «God bebyggd miljö» med delmålet «Byggnaders påverkan på hälsan».

Den svenske strategien når det gjelder PCB i bygninger er at fugemasser med høyere innhold av PCB enn 500 ppm skal saneres så snart som mulig. Motivet er at PCB er både et miljø- og et helseproblem. Man erfarer at PCB kan påvirke innemiljøet. Arbeidet ble påbegynt som et frivillig tiltak fra eiendomsbesitterne. Det frivillige tiltaket vil nå bli erstattet med en forordning med et lignende innhold.

Forordningen foreslås bl.a. å innebære at eiendomsbesitterne må kartlegge hvilke fuge- eller gulvmasser som inneholder PCB. Kartleggingen skal innberettes til tilsynsmyndigheten. Slike masser som inneholder mer enn 0,05 vektprosent PCB skal saneres senest 31. desember, 2010 for hus bygget i perioden 1956-1969 og senest 31. desember, 2012 for hus bygget i årene 1970-1973 og for industribygninger. 
Lokalt har man innen et antall län og kommuner startet prosjekt som i første omgang omfatter kartlegging av PCB. Et eksempel er prosjektet PCB-Fria Fogar i Västra Götalands län. Dette finnes beskrevet på webplassen for Miljösamverkan Västra Götaland.

PCB-prosjekt har også blitt gjennomført i flere län og i mange kommuner. Kommunenes miljøkontor har gått ut med informasjon til eiendomsbesitterne og oppfordret dem til å kartlegge PCB og meddele resultatet till miljøkontorene. Meldinger kreves innlevert innen saneringsarbeidene startes opp, og om det finnes ressurser, så følges arbeidet opp med tilbud på plassen.

Norske mål og strategier

Norske myndigheters mål og strategier er nedfelt i Stortingsmeldinger, som er meldinger om virksomhet i staten eller om planer som Regjeringen tenker å sette i verk.

Norske myndigheters handlingsplan for å redusere utslippene av PCB inneholder følgende tiltak:

- Forbud og bruksreguleringer

- PCB og produkter som innholder PCB er farlig avfall ved kassering,

- Retursystem for PCB-holdige isolerglassruter

- Øke kompetansen ved identifisering og sanering av PCB i bygg (videreføre samarbeidet med byggebransjen)

- Utvidet kontroll med PCB (trappe opp kontrollen med utfasing og avfallshåndtering)

- Fjerning av PCB fra forurenset grunn og sedimenter

- Internasjonal innsats for å fjerne langtransportert PCB

- Bedre kunnskap om spredning og effekter av PCB

Danske mål og strategier

PCB er først nå i ferd med å bli et tema i Danmark. Det finnes derfor ennå ingen egen strategi for PCB i danske bygninger.

Finske mål og strategier

Finske myndigheters mål og strategier er følgende:

- PCB-holdige installasjoner (f.eks. kondensatorer osv.) skal tas ut av bruk senest 31.12.1999

- PCB skal tas hensyn til ved renovering (f.eks. fugemasser og isolerglassruter)

- PCB-holdige fuger skal saneres på en trygg måte og PCB-holdig avfall skal deponeres på en forsvarlig måte 
Den finske strategien for PCB-holdige fugemasser er at massene skal saneres i samband med at fasaden renoveres. Man har her valgt en helt annen strategi enn Sverige.

\subsubsection{De nordiske landenes ulike arbeidsmåter}

De nordiske landene har først valgt å angripe storskala industriell anvendelse av PCB. Anvendelsen av PCB i høyspent elektrisitetsforsyning har i særklasse vært den største. Her synes de nordiske landene å ha nådd langt. På konferansen i mars 2005 ble ikke resultatet av dette arbeidet diskutert. Først og fremst ble arbeidet med PCB innen byggenæringen diskutert. Dette er en sektor der man ikke har nådd så langt som innen elforsyning. Noen tydelige forskjeller mellom de nordiske landene beskrives i det følgende.

Den svenske måten å arbeide på har vært preget av at Sverige var så tidlig ute med sitt forbud mot PCB. Dette medførte at problemet med PCB i småkondensatorer og isolerglassruter er mindre i Sverige enn i nabolandene. Naturvårdsverket har derfor ikke på samme måte som SFT arbeidet med PCB innen f.eks. byggenæringen. Når problemet med PCBforurensning fra fugemasser ble oppdaget så etablerte den svenske byggenæringen et samarbeid gjennom Kretsloppsrådet som dro i gang prosjektet «PCB i byggnader» (1998-2003). Rådet tok i stor utstrekning over Naturvårdsverkets tilsynsveiledning. Natutvårdsverket bidro med kompetanse, men ikke med operative ressurser. Høsten 2001 fikk Naturvårdsverket et regjeringsoppdrag, å utarbeide et forslag til hvordan arbeidet med å sanere PCB skulle kunne fremskyndes.

Den norske måten å arbeide på ble innledet med at SFT gjorde grundige undersøkelser av hvordan PCB-problemet innen byggenæringen ser ut. Ut fra disse undersøkelsene gjorde SFT vurderinger av hvordan de ulike forekomstene av PCB i bygninger burde angripes. Om isolerglassruter og kondensatorer i lysrørarmaturer formulerte SFT tydelige strategier. SFT har hele tiden hatt en operativ orientering og flittig produsert råd og veiledninger. Samtidig har bransjen (byggenæringen) tatt initiativet til ytterligere kartlegginger og utvikling av veiledninger og opplæringstiltak (kurs) og spiller i dag en sentral rolle både som pådriver og veileder innen PCB-spørsmål.

I Danmark har oppmerksomheten til nå overveiende vært rettet mot PCB i elektriske installasjoner som for eksempel oljer i transformatorer. PCB i åpen anvendelse i bygninger har ikke hatt samme fokus og blant de sentrale aktørene finnes en brist med hensyn til kunnskap om PCB når det gjelder bygningsmaterialer og det finnes ikke en klar praksis for utsortering av PCB-holdig bygg- og rivningsavfall. Bortskaffelse av PCB-holdig avfall har vært regulert siden 1986 (revidert 1998). Avfall som inneholder mer enn 0,005 vektprosent PCB, skal håndteres som farlig avfall, Derfor 
har kommunene ansvaret for å samle inn avfallet. Miljøstyrelsen har dessuten sendt brev til kommunene i 2001 og 2004 om at PCB-holdig avfall skal håndteres som farlig avfall, dersom det inneholder mer enn 0,05 vektprosent PCB.

I Finland har myndighetene ikke betraktet PCB-holdige fugemasser som noe større problem. Sanering av PCB-holdige fuger skal utføres først når bygningen skal renoveres, f.eks. ved en fasaderenovering. Miljöministeriet har utarbeidet veiledninger for hvordan man skal gå til verks ved en fasaderenovering av en bygning med PCB-holdige fuger. Dessuten finnes veiledninger fra myndighetene om hvordan arbeiderne skal beskyttes ved en $\mathrm{PCB}$-sanering.

På Island har myndighetene den oppfatningen at PCB hovedsakelig er anvendt på elkraftsiden. Anvendelsen i bygninger er dårlig kjent, men synes ha vært liten og stort sett begrenset til fugemasser og isolerglassruter. Kunnskapen om PCB i bygninger er imidlertid liten og problemet synes ikke å være tilstrekkelig kjent verken på myndighetssiden eller innen byggenæringen.

I Reykjavik ble regelverk med hensyn til godkjenning av rivearbeider og krav til utsortering av helse- og miljøfarlige stoffer implementert i 2001. I prinsippet skal dette regelverket gjelde for hele Island, men dette er ikke tilfelle alle steder.

Lov- og regelverk i tabell 4 gir en oversikt over lov- og regelverk som er spesielt relevant i forhold til PCB i bygninger. Det gjøres oppmerksom på at nivåene på lov- og regelverk kan være ulikt i de forskjellige land og at de således ikke nødvendigvis gir samme fullmakt eller hjemmel. 
Tabell 4. Gjeldende lov- og regelverk vedrørende PCB i de nordiske land.

\begin{tabular}{|c|c|c|c|}
\hline & Lover & Forordninger, forskrifter & $\begin{array}{l}\text { Retningslinjerl } \\
\text { veiledninger }\end{array}$ \\
\hline SE & $\begin{array}{l}\text { Miljöbalken }^{2} \\
\text { Arbetsmiljölagen }^{4} \\
\text { Plan- och bygglagen }\end{array}$ & $\begin{array}{l}\text { Förordning om PCB mm. Förord- } \\
\text { ning om bortskaffande av PCB } \\
\text { mm. Avfallsförordning. Förordning } \\
\text { om avfallsförbränning. Förordning } \\
\text { om producentansvar för elektriska } \\
\text { och elektroniska produkter. För- } \\
\text { ordning om deponering av avfall. } \\
\text { Hygieniska gränsvärden och } \\
\text { åtgärder mot luftföroreningar. } \\
\text { (Arbetsmiljöverket). Föreskrifter om } \\
\text { transportdokument för transport av } \\
\text { farligt avfall (Naturvårdsverket) } \\
\text { Föreskrifter för transport av farligt } \\
\text { gods (Räddningsverket) }\end{array}$ & $\begin{array}{l}\text { Generella riktvärden } \\
\text { för förorenad mark. } \\
\text { Rapport 4638, Natur- } \\
\text { vårdsverket. } \\
\text { Anvisningar för tillsyn } \\
\text { från Arbetsmiljöverket: } \\
\text { Vägledning för kontroll } \\
\text { av arbetsmiljön vid } \\
\text { sanering av PCB- } \\
\text { fogar under } 2003\end{array}$ \\
\hline NO & $\begin{array}{l}\text { Forrensningsloven }{ }^{39} \\
\text { Produktkontrolloven } \\
\text { Arbeidsmiljøloven }^{41}\end{array}$ & $\begin{array}{l}\text { Produktforskriften }{ }^{44} \\
\text { Kap. } 2 \text { Regulerte stoff eller stoff- } \\
\text { blandinger } \\
\text { Kap. } 3 \text { Regulerte produktgrupper } \\
\text { Avfallsforskriften }{ }^{42} \\
\text { Kap. } 11 \text { Farlig avfall } \\
\text { Kap. } 14 \text { Kasserte PCB-holdige } \\
\text { isolerglassruter }\end{array}$ & $\begin{array}{l}\text { SFT 99:01 Veiledning } \\
\text { om risikovurdering av } \\
\text { forurenset grunn }{ }^{47} \\
\text { Arbeidstilsynets } \\
\text { veiledning om Admi- } \\
\text { nistrative normer for } \\
\text { forurensning i arbeids- } \\
\text { atmosfære } 2003^{61}\end{array}$ \\
\hline DK & $\begin{array}{l}\text { BEK nr } 1042 \text { af } \\
\underline{17 / 12 / 1997} \\
\text { Bekendtgørelse om } \\
\text { begrænsning af salg og } \\
\text { anvendelse af visse farlige } \\
\text { kemiske stoffer og produk- } \\
\text { ter til specielt angivne } \\
\left.\text { formål( }{ }^{*} 1\right) \\
\text { BEK nr } 925 \text { af 13/12/1998 } \\
\text { Bekendtgørelse om PCB, } \\
\text { PCT og erstatningsstoffer } \\
\text { herfor } \\
\text { BEK nr } 619 \text { af } 27 / 06 / 2000 \\
\text { Bekendtgørelse om affald } \\
\text { BEK nr } 664 \text { af } 27 / 06 / 2005 \\
\text { Bekendtgørelse om } \\
\text { håndtering af affald af } \\
\text { elektrisk og elektronisk } \\
\text { udstyr } \\
\text { (Elskrotbekendtgørel- } \\
\text { sen)1)/NREF/FN501/1) }\end{array}$ & $\begin{array}{l}\text { CIS nr } 3275 \text { af 20/05/1988 } \\
\text { At-cirkulæreskrivelse om Be- } \\
\text { grænsning i anvendelsen af PCB } \\
\text { og PCT (* } 1) \\
\text { VEJ nr } 60309 \text { af 01/10/1994 } \\
\text { Bortskaffelse, planlægning og } \\
\text { registrering af affald } \\
\text { VEJ nr } 9580 \text { af } 20 / 10 / 2004 \\
\text { Vejledning om klassificering m.v. af } \\
\text { kemiske stoffer og produkter } \\
\text { VEJ nr } 9709 \text { af } 01 / 12 / 2004 \\
\text { Opdateret vejledning om kommu- } \\
\text { nale affaldsplaner }\end{array}$ & \\
\hline FIN & $\begin{array}{l}\text { Miljöskyddsloven }^{73} \\
\text { Markanvändings- och } \\
\text { byggloven } \\
\text { Arbetarskyddslag } \\
\text { Avfallslag (1072/1993) }\end{array}$ & $\begin{array}{l}\text { Markanvändings- och byggförord- } \\
\text { ning } \\
\text { Miljöskyddsförordning } \\
\text { Avfallsförordningen (1390/1993) } \\
\text { Statsrådets beslut om tagande ur } \\
\text { bruk av PCB och PCB-utrustning } \\
\text { samt behandlind av PCB-avfall } \\
\text { Statsrådets beslut om begränsning } \\
\text { av användningen av PCB och PCT } \\
\text { Arbetatsskyddmyndigheternnas } \\
\text { föreskrifter om trygg renovering } \\
\text { metoder vid fasadrenovering och } \\
\text { PCB }\end{array}$ & \\
\hline IS & $\begin{array}{l}\text { Lov nr. 7/1998 om miljø og } \\
\text { forurensningskontroll } \\
\text { Lov nr. 52/1988 om farlige } \\
\text { kjemikalier }\end{array}$ & $\begin{array}{l}\text { Forskrift nr. 323/1998 om import, } \\
\text { bruk, omsetning m.m. av PCB, } \\
\text { PCT og andre miljøfarlige erstat- } \\
\text { ningsstoffer }\end{array}$ & $\begin{array}{l}\text { Ingen retningslinjer } \\
\text { eller veiledninger } \\
\text { vedrørende PCB i } \\
\text { bygninger. }\end{array}$ \\
\hline
\end{tabular}




\subsubsection{Myndighetsutøvelse}

Det er i følge lovgivningen ingen krav om omgående sanering av PCBholdige forekomster bortsett fra i enkelte utvalgte anvendelser. Disse krav fremkommer som regel i forskrift i form av forbud mot bruk. I enkelte land har myndighetene pålagt bl.a. produsentene et ansvar for å etablere og drive returordninger for PCB-holdige produkter. Forbudene og påleggene må følges opp av kontroller og øvrige virkemidler for å virke etter sin hensikt. De viktigste eksempler på myndighetsutøvelse er vist i tabell 5 og tabell 6.

Tabell 5. Gjeldende og kommende forbud med hensyn til PCB i de nordiske land.

\begin{tabular}{|c|c|c|}
\hline & Gjeldende forbud & $\begin{array}{l}\text { Kommende forbud } \\
\text { eller forventede forbud }\end{array}$ \\
\hline SE & $\begin{array}{l}\text { Ingen forbud finnes i dag mot pågående bruk av } \\
\text { PCB i produkter i bygninger. } \\
\text { Produkter med PCB tillates ikke fremstilt, bear- } \\
\text { beidet, omsatt eller overlatt for bruk eller om- } \\
\text { bruk. Produktene eller varene tillates ikke } \\
\text { importert fra eller eksportert til land som ikke er } \\
\text { medlemmer i den Europeiske Unionen. Innen } \\
\text { EU får produkter med PCB kun tas imot som } \\
\text { avfall. }\end{array}$ & $\begin{array}{l}\text { Sannsynligvis i samsvar med den } \\
\text { kommende forordningen: Forbud mot å } \\
\text { ha fuge- og gulvmasser med mer enn } \\
0,05 \text { vektprosent PCB forekommende i } \\
\text { bygninger etter } 2010 \text { resp. } 2012 \text { for } \\
\text { ulike byggeår. }\end{array}$ \\
\hline NO & $\begin{array}{l}\text { Det er forbudt å produsere, importere, eksporte- } \\
\text { re, omsette og bruke stoff eller stoffblandinger } \\
\text { som inneholder PCB. } \\
\text { Forbud mot å ha i bruk: } \\
\text { PCB-holdige kondensatorer i innendørs lysrør- } \\
\text { armaturer og utendørs damplampearmatur er } \\
\text { gjeldende fra 01.01.2005, men muligheter for } \\
\text { utsettelse til 31.12.2007 under gitte betingelser } \\
\text { PCB-holdige transformatorer og større konden- } \\
\text { satorer }\end{array}$ & $\begin{array}{l}\text { Forbud fra 01.01.2010 mot å ha i bruk } \\
\text { PCB-holdige strømgjennomføringer, } \\
\text { transformatorer eller gjennom veggma- } \\
\text { teriale i kraftstasjoner og lignende } \\
\text { anlegg }\end{array}$ \\
\hline & $\begin{array}{l}\text { Der er forbudt at anvende PCB. } \\
\text { Avfall som inneholder mer enn } 0,05 \text { vektprosent } \\
\text { PCB betraktes som farlig avfall. }\end{array}$ & $\begin{array}{l}\text { Ingen kjente kommende eller forvente- } \\
\text { de forbud }\end{array}$ \\
\hline FIN & $\begin{array}{l}\text { Statsrådets vedtak om utfasing av PCB og PCB- } \\
\text { holdige installasjoner samt behandling av PCB- } \\
\text { holdig avfall: } \\
\text { PCB-holdige installasjoner må tas ut av bruk } \\
\text { senest 31.12.1999 } \\
\text { Statsrådets vedtak om begrenset anvendelse av } \\
\text { PCB og PCT: } \\
\text { Det er forbudt å fremstille, importere, omsette } \\
\text { eller overlate PCB, PCT og produkter som } \\
\text { inneholder disse stoffene }\end{array}$ & $\begin{array}{l}\text { Ingen kjente kommende eller forvente- } \\
\text { de forbud }\end{array}$ \\
\hline IS & $\begin{array}{l}\text { Krav i forskrift nr. 323/1998 setter forbud mot } \\
\text { import og omsetning av PCB-holdige produkter } \\
\text { og krav til hvordan PCB-holdig avfall skal dispo- } \\
\text { neres. } \\
\text { Forskriften inneholder ikke tidsfrister for utfasing } \\
\text { av PCB. }\end{array}$ & $\begin{array}{l}\text { Ingen kjente kommende eller forvente- } \\
\text { de forbud }\end{array}$ \\
\hline
\end{tabular}


Tabell 6. Plikter, kontroll og virkemidler med hensyn til PCB i de nordiske land.

\begin{tabular}{|c|c|c|c|}
\hline & Plikter int regelverket & Kontroll & Øvrige virkemidler \\
\hline SE & $\begin{array}{l}\text { Angående farlig avfall som } \\
\text { oppstår ved riving - krav om } \\
\text { rivningsplan. } \\
\text { Krav om kartlegging av PCB i } \\
\text { bygninger (kunnskapskravet i } \\
\text { Miljöbalken). } \\
\text { Krav til melding om sanering } \\
\text { av PCB. } \\
\text { Krav til hensyn til ytre miljø, } \\
\text { arbeidsmiljø og andre men- } \\
\text { neskers helse ved sanerings- } \\
\text { arbeider samt krav til håndte- } \\
\text { ring, transport, dokumenta- } \\
\text { sjon og behandling av det } \\
\text { farlige avfallet. } \\
\text { Krav til bedriftenes egenkont- } \\
\text { roll. } \\
\text { Krav om forbehandling av } \\
\text { elektriske og elektroniske } \\
\text { produkter som er avfall. }\end{array}$ & $\begin{array}{l}\text { Den lokale tilsynsmyndig- } \\
\text { heten (i praksis miljøkonto- } \\
\text { rene) har den løpende } \\
\text { kontrollen. Tilsyn utføres i } \\
\text { lite omfang grunnet res- } \\
\text { sursmangel. } \\
\text { Arbetsmiljöverket regionalt } \\
\text { har ansvaret for kontroll av } \\
\text { at arbeidsmiljøregelverket } \\
\text { følges. }\end{array}$ & $\begin{array}{l}\text { PCB-prosjekt i län og } \\
\text { kommuner. }\end{array}$ \\
\hline NO & $\begin{array}{l}\text { Produsenter av isolerglassru- } \\
\text { ter er pålagt å etablere retur- } \\
\text { ordninger, jf. Avfallsforskriften } \\
{ }^{42} \text { Kap. } 14 \text { (se avsnitt neden- } \\
\text { for). } \\
\text { Forhandlere, produsenter, } \\
\text { returselskap og kommunene } \\
\text { plikter å sørge for en veder- } \\
\text { lagsfri returordning for kasser- } \\
\text { te elektriske og elektroniske } \\
\text { produkter, jf. Avfallsforskriften } \\
{ }^{42} \text { Kap. } 1 \text { (se avsnitt neden- } \\
\text { for). }\end{array}$ & $\begin{array}{l}\text { Miljømyndighetene gjen- } \\
\text { nomfører kontroller i } \\
\text { forhold til om produsente- } \\
\text { ne overholder sine plikter, } \\
\text { utfasing av produkter som } \\
\text { ikke er lov å ha i bruk og } \\
\text { håndtering av PCB-holdig } \\
\text { avfall. }\end{array}$ & $\begin{array}{l}\text { Informasjon fra SFT og } \\
\text { andre berørte myndigheter. } \\
\varnothing \text { konomiske bidrag til } \\
\text { kampanjer for å fremme } \\
\text { innsamlingen av PCB- } \\
\text { holdige produkter. }\end{array}$ \\
\hline DK & $\begin{array}{l}\text { PCB skal utsorteres og } \\
\text { disponeres som farlig avfall. } \\
\text { Avfall som inneholder mer } \\
\text { enn } 0,005 \text { vektprosent PCB } \\
\text { betraktes som farlig avfall. }\end{array}$ & & $\begin{array}{l}\text { Dansk Byggeri, Nedriv- } \\
\text { ningssektionen vurderer et } \\
\text { supplement til NK96, } \\
\text { Brancheaftale om selektiv } \\
\text { nedrivning. }\end{array}$ \\
\hline FIN & $\begin{array}{l}\text { Mengden og håndteringen av } \\
\text { farlig avfall som oppstår ved } \\
\text { riving - krav om rivningsplan } \\
\text { Krav om kartlegging av PCB } \\
\text { og andre farlige stoffer i } \\
\text { bygninger som skal rehabilite- } \\
\text { res. } \\
\text { Krav om at byggavfall skal } \\
\text { sorteres og at farlig avfall } \\
\text { deponeres på en forsvarlig } \\
\text { måte. }\end{array}$ & $\begin{array}{l}\text { Miljømyndighetene (kom- } \\
\text { munale og regionale): } \\
\text { - byggeplasser } \\
\text { - avfallsmottak/-anlegg } \\
\text { Arbeidsmiljømyndighetene } \\
\text { Bygningskontrollen }\end{array}$ & \\
\hline IS & $\begin{array}{l}\text { PCB skal kartlegges og } \\
\text { håndteres som farlig avfall. }\end{array}$ & $\begin{array}{l}\text { Lokale helsemyndigheter } \\
\text { under kontroll av det } \\
\text { islandske forurensningstil- } \\
\text { syn (UST). } \\
\text { Arbeidstilsynet }\end{array}$ & $\begin{array}{l}\text { Lokale helsemyndigheter } \\
\text { under kontroll av det } \\
\text { islandske forurensningstil- } \\
\text { syn (UST) }\end{array}$ \\
\hline
\end{tabular}

\section{Eksempler på regler og myndighetsutøvelse i Sverige}

Reglene om produsentansvar innebærer at produsentene får ansvar for alt elektrisk og elektronisk avfall. Husholdningene leverer dette avfallet uten kostnad. Avfallsforordningen stiller blant annet krav til forbehandling av 
alt elektrisk og elektronisk avfall hvilket gjør at kondensatorer med PCB i hovedsak tas hånd om på en forsvarlig måte.

Eksempler på regler og myndighetsutøvelse i Norge

Kasserte PCB-holdige isolerglassruter

Produsenter (importør eller produsent) av isolerglassruter har plikt til å sørge for at enhver avfallsbesitter kan levere kasserte PCB-holdige isolerglassruter til forsvarlig behandling mot et vederlag som ikke overstiger normalpris for levering av isolerglassruter uten PCB til vanlige avfallsmottak. Produsenten må dekke merkostnadene utover dette. Produsenter har også plikt til å sørge for tilstrekkelig informasjon til avfallsbesitter om at PCB-holdige isolerglassruter inngår i et system for retur og forsvarlig behandling og hvor de kan leveres. Produsenter skal uoppfordret informere sine kunder om hvilke ruter som kan tenkes å inneholde PCB. Pliktene for hver produsent omfatter den forholdsmessige andel av kasserte PCBholdige isolerglassruter som tilsvarer vedkommendes markedsandel for isolerglassruter til det norske markedet.

Kasserte elektriske og elektroniske produkter (EE-avfall)

Elektriske og elektroniske produkter som inneholder PCB-holdige komponenter og alle andre elektriske og elektroniske produkter skal leveres inn til godkjent returordning. Her har både forhandler, kommune, produsent og returselskap ulike plikter:

- Forhandlere har plikt til å ta EE-avfall vederlagsfritt i retur ved sitt forretningssted og sørge for videresending av avfallet til godkjent oppsamlingsplass eller behandlingsanlegg.

- Kommuner har plikt til å sørge for at det eksisterer et tilstrekkelig tilbud om vederlagsfritt mottak av EE-avfall fra husholdninger og sørge for videresending av avfallet til godkjent oppsamlingsplass eller behandlingsanlegg. Kommunen har også plikt til å ta imot EE-avfall fra næringsvirksomheter, men kan kreve vederlag for dette.

- Produsent og returselskap har plikt til å sørge for vederlagsfri henting av EE-avfall fra forhandlere og kommuner og sortering, gjenvinning og annen forsvarlig behandling av EE-avfall. Produsent kan oppfylle sine plikter gjennom deltakelse i et returselskap. Med returselskap menes enhver virksomhet som etter avtale påtar seg oppfyllelsen av plikter for en eller flere produsenter. Returselskap må årlig rapportere mengder og typer EE-avfall som er innsamlet og behandlet til myndighetene.

Alle aktørene har dessuten plikt til å informere om returordningen. Gjennom en slik pålagt returordning ivaretas håndteringen av PCB-holdig EEavfall, som f.eks. kondensatorer i lysrørarmaturer. 
Eksempler på regler og myndighetsutøvelse i Danmark

Utsortering av PCB (i åpen anvendelse slik som elastiske fuger) fra byggavfall i forbindelse med riving og rehabilitering er ikke utbredt praksis i Danmark. En forespørsel blant større danske riveentreprenører viser kun kjennskap til to tilfeller hvor sanering av PCB er blitt utført. Begge tilfeller er nye saker fra 2005/2006 utført i København kommune.

Elektrisk og elektronisk avfall med PCB, transformatorer mv. håndteres av egne godkjente behandlingsanlegg.

Eksempler på regler og myndighetsutøvelse i Finland

I Finland finnes blant annet følgende eksempler på myndighetsutøvelse:

- Levering av PCB-holdige elektriske og elektroniske produkter skal være gebyrfritt for husholdninger.

- PCB-holdig avfall må håndteres/behandles på en forsvarlig måte i godkjente avfallsbehandlingsanlegg.

- Lokale myndigheter gir veiledning til avfallsentreprenørene og behandlingsanleggene.

\subsubsection{Bransjeinitiativ}

I tillegg til lov- og regelverk og myndighetsutøvelse er bransjeinitiativ et viktig virkemiddel for å oppnå kontroll med PCB i bygg. Av tabell 7 fremgår hvilke bransjeinitiativ som er kjent for de ulike forekomster av PCB pr dags dato i de nordiske land. 
Tabell 7. Bransjeinitiativ og -ansvar vedrørende РСВ i de nordiske land.

\begin{tabular}{|c|c|c|c|c|c|c|c|c|}
\hline & 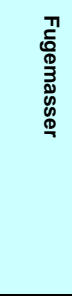 & 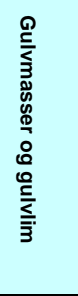 & 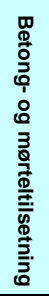 & 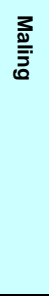 & 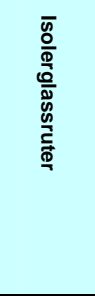 & 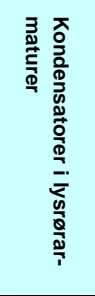 & 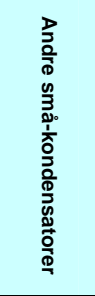 & 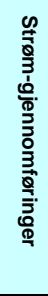 \\
\hline SE & \multicolumn{2}{|c|}{$\begin{array}{l}\text { Byggsektorens } \\
\text { forpliktelse til å } \\
\text { kartlegge og sanere } \\
\text { fuge- og gulvmasser }\end{array}$} & & & \multicolumn{3}{|c|}{$\begin{array}{l}\text { Byggsektorens forpliktelse } \\
\text { til å kartlegge }\end{array}$} & \\
\hline$\frac{}{2}$ & & & & & $\begin{array}{l}\text { Rutere- } \\
\text { tur } \\
\text { (retur- } \\
\text { sel- } \\
\text { skap) }\end{array}$ & $\begin{array}{l}\text { RENAS } \\
\text { (retur- } \\
\text { sel- } \\
\text { skap) }\end{array}$ & $\begin{array}{l}\text { RENAS } \\
\text { (retur- } \\
\text { sel- } \\
\text { skap) }\end{array}$ & \\
\hline DK & & & & & & & & \\
\hline FIN & & & & & & & & \\
\hline IS & & & & & & & & \\
\hline
\end{tabular}

Ingen kjente bransjeinitiativ

I tillegg til bransjeinitiativene som fremgår av tabell 7 er det også en rekke andre initiativ som på en bredere front fremmer arbeidet med å få økt kontroll med PCB i bygg.

\section{Bransjeinitiativ i Sverige}

I 1998 gjorde eiendomsbesitterne i Sverige gjennom Kretsloppsrådet en beslutning om å kartlegge og sanere PCB. Beslutningen innebar at alle PCB-holdige produkter i bygninger skulle kartlegges, at åpne spredningskilder (fugemasser, gulvmasser) skulle saneres innen årsskiftet 2002/2003 og at isolerglassruter og kondensatorer skulle tas hånd om på en forsvarlig måte ved utskifting eller riving. Ettersom målene for prosjektet «PCB i byggnader», som formulerte tiltaket, ikke har blitt oppfylt, ventes nå en forordning med omtrent de samme krav.

Det tidligere prosjektet «PCB i byggnader» drev et omfattende informasjonsarbeid om PCB. Informasjonsarbeidet drives nå videre av Miljö konsultgruppen i Stockholm HB gjennom bl.a. webplassen www.sanerapcb.nu og seminarer. 
Svenska Fogbranschens Riksförbund (SFR) utdanner fugesanerere og har gitt ut en veiledning for saneringsarbeide.

Et antall FoU-prosjekt for å få mer kunnskap og utvikle arbeidsmetoder har blitt gjennomført eller pågår. Eksempler er studier og utvikling av saneringsmetoder innen prosjektet «PCB i byggnader», studier av PCBspredning fra fugemasser til tilgrensende material, studier av PCB og annet helsefarlig tll luft ved fugesanering og studier av PCB-konsentrasjoner i innemiljøet. I litteraturlisten i kapittel 6 finnes en oversikt over rapportene fra de prosjektene som er ferdigstilt, både prosjekt som myndigheter har tatt initiativ til og prosjekt som er startet innen foretak og organisasjoner innen byggenæringen.

Utvikling av arbeidsmetoder og verktøy pågår også fortløpende hos seriøse foretak som utfører fugesanering. Verdifulle forbedringer tas inn i den veiledning for fugesanering som gis ut av SFR.

Elektro og elektronikkbransjen har etablert Elkretsen AB for å løse produsentansvaret for elektrisk og elektronisk avfall. Privatpersoners avfall tas imot uten avgift av Elretur, et felles innsamlingssystem som kommunene og produsentene samarbeider om. Elreturs mottaksstasjoner drives vanligvis av kommunene. Men hjemmeelektronikk slik som TV, radio, video m.m. leveres til butikk ved kjøp av nye tilsvarende produkter. Foretak og organisasjoner får et eget innsamlingssystem, normalt en mottaksplass i hver kommune. Fra mottaksstasjonen transporteres de kasserte elektriske og elektroniske produktene til spesialiserte gjenvinningsanlegg. Produsentene organiserer og finansierer transporten og behandlingen gjennom El-Kretsen AB, som er et non-profit foretak. Produsentforetakene betaler de innkrevde avgifter til El-Kretsen AB. ElKretsen $\mathrm{AB}$, produsentene og kommunene vil med Elretur bidra til et bedre miljø.

Innsamlingssystemet fungerer bra og bidrar til å redusere risikoen for at PCB-holdige kondensatorer kommer på avveie.

Bransjeinitiativ i Norge

I Norge har byggebransjen ved Byggenæringens Landsforening (BNL) tatt initiativet til en Nasjonal Handlingsplan for bygg og anleggsavfall. Handlingsplanen inneholder tiltak om etablering av en gratis returordning for isolerglassruter, kartlegging av PCB i fuger, mørtel og maling og utarbeidelse av veiledningsmateriell for sanering av PCB. Disse tiltakene er i stor grad gjennomført og omtalt i denne rapporten.

Byggebransjen og elektrobransjen har etablert to viktige returselskaper for mer enn halvparten av den gjenværende mengde PCB i norske bygg, hhv Ruteretur og RENAS.

\section{Ruteretur}

En bransjeavtale ble inngått den 30. april 2002 mellom Miljøverndepartementet og bransjen representert ved Foreningen Næringseiendom, 
Glassbransjeforbundet i Norge, Norges Bygg- og Eiendomsforening, Norske Trevarefabrikkers Landsforbund og Trelast- og Byggevarehandelens Fellesorganisasjon. Gjennom avtalen forpliktet bransjen seg til å

- etablere et retursystem innen 1.7.2002

- etablere en vederlagsordning/finansiering av ordningen

- sikre et effektivt kostnadsnivå

- drive informasjon

- rapportere til myndighetene

Ruteretur AS har avtaler om deltagelse i returordningen med nasjonale produsenter og importører av isolerglass eller produkter der isolerglass er benyttet. Deltakerne betaler et vederlag til returordningen for hver rute som sendes ut på det norske markedet. Vederlaget finansierer delvis den etablerte returordningen for PCB-holdige isolerglassruter i Norge, slik at levering av kasserte PCB-holdige isolerglassruter til forsvarlig behandling ikke skal koste mer enn normalpris for levering av isolerglassruter uten PCB til vanlige avfallsmottak.

Returselskapet for næringselektro (RENAS)

RENAS ble stiftet 7. august 1997 av Elektroforeningen (EFO) og TBL Elektro, og eies av de to bransjeorganisasjonene med $50 \%$ hver. RENAS skal ivareta medlemmenes plikter i henhold til Avfallsforskriften Kap. 1 og virksomheten er regulert gjennom en bransjeavtale med Miljøverndepartementet.

På samme måte som for Ruteretur er det en vederlagsordning der inntektene fra miljøgebyr på kjøp av nye produkter skal finansiere driften av en ordning for innsamling, behandling og gjenvinning av kasserte elektriske og elektroniske produkter (EE-avfall).

Private kan levere EE-avfall gratis til kommunale avfallsmottak, eller til butikker som selger produkt i tilsvarende kategori som det som skal kastes. Bedrifter kan også levere til disse stedene, men kan bli belastet et gebyr, eller pålegges krav om gjenkjøp av nye produkter.

En viktig oppgave for selskapet er å sørge for en effektiv og forsvarlig håndtering av helse- og miljøskadelige stoffer i EE-avfallet, deriblant PCB i kondensatorer.

\section{Bransjeinitiativ i Danmark}

Den danske nedrivningsbransjen har en egen bransjeavtale om selektiv riving. Denne planlegges utvidet med retningslinjer for utsortering av PCB og andre miljøfarlige stoffer.

\section{Bransjeinitiativ i Finland}

Den finske byggeindustrien samarbeider med miljømyndighetene, men har ingen spesiell strategi med hensyn til PCB i bygninger. 
Bransjeinitiativ på Island

Den islandske byggeindustrien samarbeider med miljømyndighetene, men har ingen spesiell strategi med hensyn til PCB i bygninger.

\subsubsection{Standardisering / kontrollordninger}

Standardisering og kontrollordninger kan være med på å heve kvaliteten på de arbeider som gjøres med å kartlegge og sanere PCB i bygg. Gode eksempler på dette er vist i det følgende.

Standardisering og kontrollordninger i Sverige

I utviklingsprosjekt har konsulentforetak og fugesaneringsforetak samt Svenska Fogbranschens Riksförbund studert og utviklet metoder og rutiner for sanering av fugemasser med PCB. Utviklingsarbeid har også blitt utført innen enkelte entreprenørbedrifter som arbeider med fugesanering. Arbetet har resultert i rapporter fra Sveriges Provnings- och Forskningsinstitut, fra FoU Väst og fra Svenska Fogbranschens Riksförbund (SFR), og Svenska Byggbranschens Utvecklingsfond (SBUF). Se litteraturlisten i kapittel 6. SFR har med den kunnskap som utviklingsarbeidet har gitt, skrevet en veiledning for hvordan sanering av PCB-holdige fugemasser bør gjennomføres. Veiledningen har ved flere anledninger blitt oppdatert med nye erfaringer, senest i januar 2005.

Fra det tidligere prosjektet «PCB i byggnader» (innen Kretsloppsrådet) og i dag fra Miljökonsultgruppen i Stockholm HB henvises det til veiledningen for alt fugesaneringarbeid og for de krav som skal stilles til slikt arbeid. Veiledningen fungerer dermed som en slags standard. Tilsynsmyndighetene (kommunene) har også god hjelp av veiledningen i sitt tilsynsarbeid.

Innen prosjektet «PCB i byggnader» ble maler for formulering av krav ved anskaffelse av fugesaneringstjenester utarbeidet. Anbefalinger er også utarbeidet for hvordan ulike byggevarer med PCB skal identifiseres i bygninger og hvordan prøver av fugemasser skal tas ut for analyse. På webplassen www.sanerapcb.nu finnes mesteparten av informasjonen samlet.

SFR i samarbeid med Miljökonsultgruppen i Stockholm utdanner entreprenører i fugesanering i henhold til veiledningen. Personer som utdannes får et kort som bevis, som kan etterspørres ved kontroll på arbeidsplassen. Bestillere (og tilsynsmyndigheter) oppfordres til å stille krav til at personell som sanerer skal ha slik utdanning.

I Sverige har Stena Fragmentering utviklet etiketter, som kan anvendes ved kartlegging for å merke f.eks. kondensatorer som inneholder eller mistenkes å inneholde PCB. Forut for riving kan også isolerglassruter merkes, slik at de ikke blir feilhåndtert ved rivingen, men kan tas hånd om på en forsvarlig måte. 


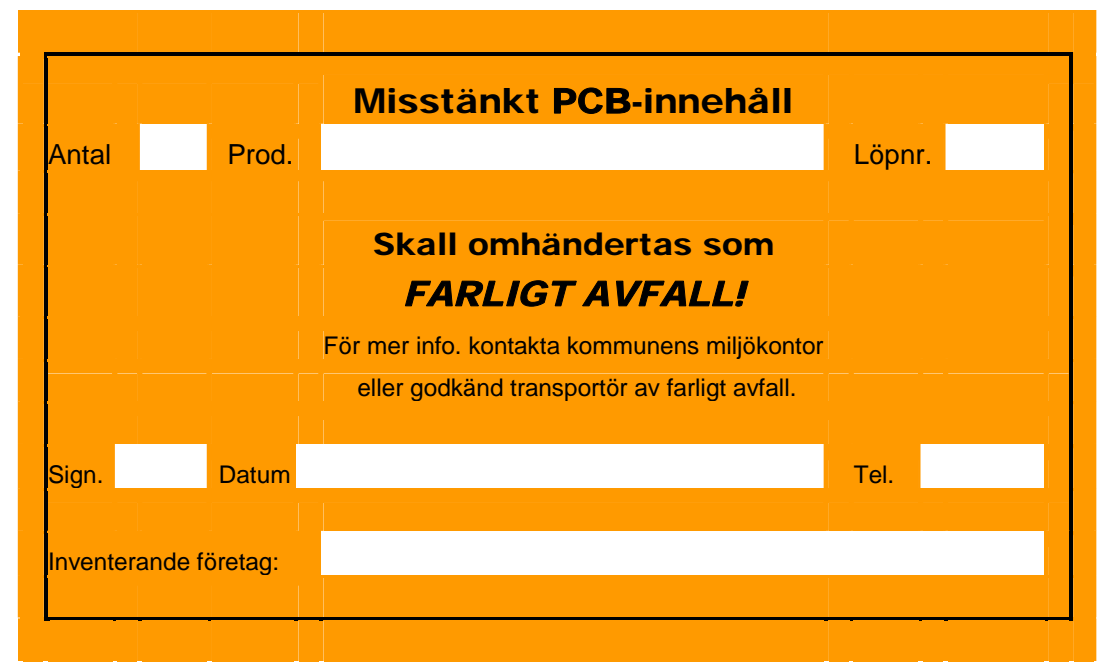

Standardisering og kontrollordninger i Norge

Sanering av PCB-holdige materialer er foreløpig ikke innarbeidet $\mathrm{i}$ NS3420 Beskrivelsestekster for bygg, anlegg og installasjoner, men forslag til beskrivelsestekster i NS3420 for de fleste forekomster av PCB er utarbeidet og finnes i veilederen Identifisering av PCB i norske bygg fra BNL.

Det er utviklet et kurs som heter PCB og arbeidsmiljø i bygg som gir utførende entreprenører tilstrekkelig kompetanse til å utføre sanering av PCB-holdige materialer på en forsvarlig måte med hensyn til både arbeidsmiljø og naturmiljø. Kurset dokumenteres med et kursbevis for de som har bestått kurset. Det finnes ingen offisiell kontroll- eller sertifiseringsordning, men kursbeviset kan benyttes som dokumentasjon på at utførende har tilstrekkelig kompetanse til å utføre oppdraget. Kursbeviset har derfor en betydning både ved byggherrens kontroll av entreprenøren og som entreprenørens dokumentasjon på tilstrekkelig kompetanse ved tilbudsgivning, prekvalifisering og lignende.

I Norge finnes standardiserte avfallssymboler. Det er utviklet et eget symbol for PCB-holdige isolerglassruter:

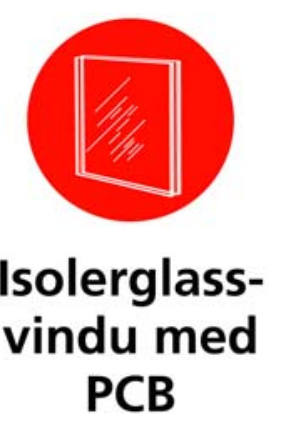

Det er også utviklet etiketter som kan klistres på isolerglassruter, som finnes på www.pcb.no. 
Standardisering og kontrollordninger i Danmark

Den danske nedrivningsbransjen har en egen bransjeavtale om selektiv riving. Denne inneholder en kontrollordning. Avtalen planlegges utvidet med retningslinjer for utsortering av PCB.

Standardisering og kontrollordninger i Finland og på Island

I Finland og på Island er det ikke kjent at det finnes noen form for standardisering eller kontrollordninger med hensyn til PCB

\subsubsection{Opplcring / informasjonstiltak}

Kompetansehevende tiltak og informasjonstiltak kan gjennomføres på mange ulike måter. Noen eksempler på tiltak er følgende (ikke heldekkende):

- Kurser og seminarer i Norge, Sverige og Finland

- Veiledninger/retningslinjer for

a) fuger i Sverige

b) maling, mørtel, fuger, kondensatorer og isolerglassruter i Norge

c) PCB forurenset jord i Finland og Norge

d) Myndighetsinformasjon

e) Bransjeinformasjon

f) Internett 
Tabell 8. Kompetansehevende tiltak med hensyn til РСВ i de nordiske land.

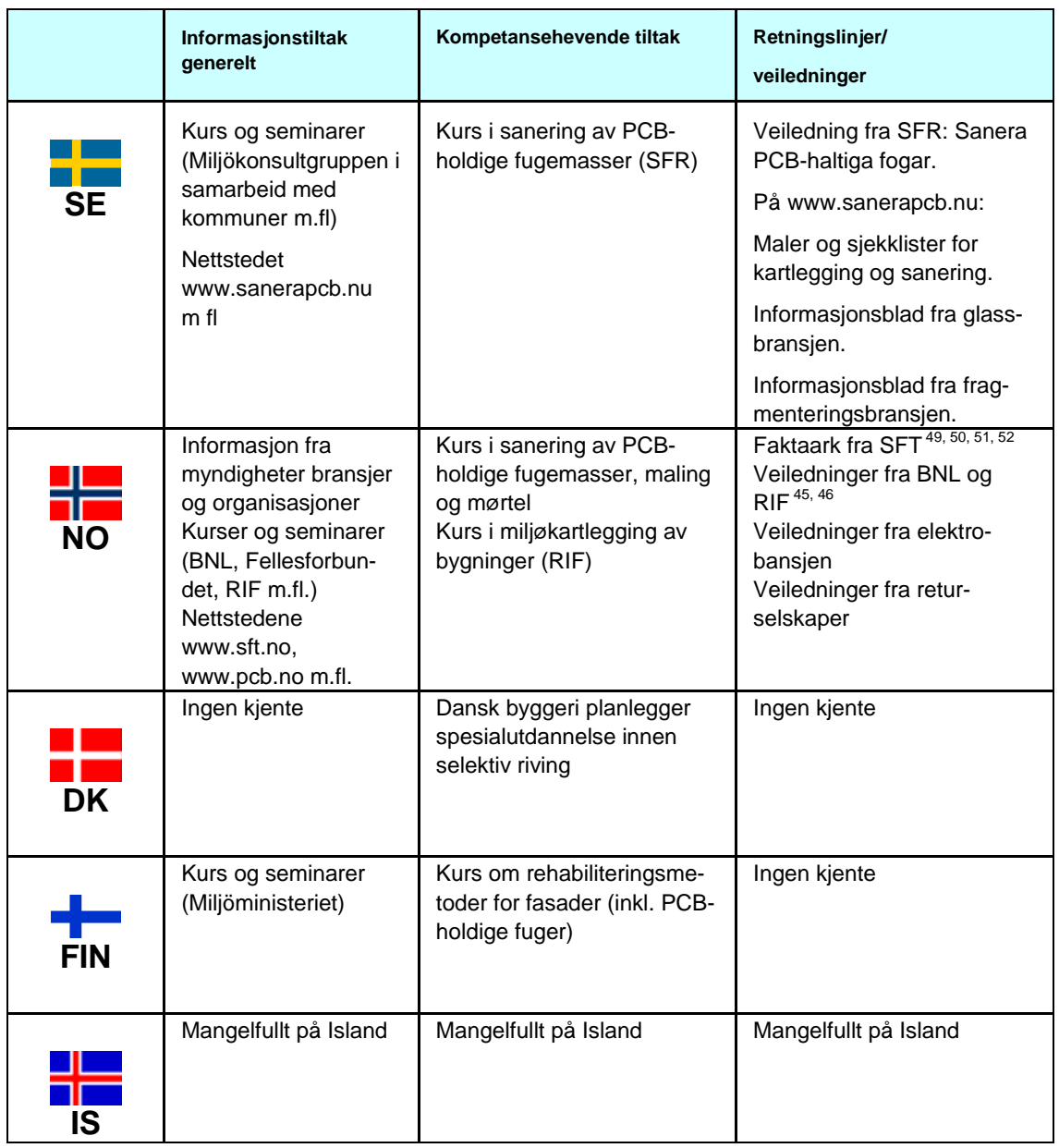

I flere land finnes også informasjon om PCB på internett, se kapittel 6.

\subsection{Teknisk utvikling}

I dette avsnitt er det gjort forsøk på å gjøre opp en status for hvor langt man har kommet i den tekniske utvikling med hensyn til kartlegging, sanering og sluttdisponering av PCB.

\subsubsection{Kartleggingsmetoder}

Selv om miljøkartlegging kreves i mange kommuner og land, kartlegges PCB i varierende grad ved riving, rehabilitering og ombygging. 
Kartlegging av PCB i Sverige

I Sverige finnes veiledninger (på www.sanerapcb.nu) for hvordan PCB i bygninger skal kartlegges. Informasjon om hvordan kartlegging av PCB skal utføres inngår i SFRs utdanning av fugesanerere.

For å identifisere PCB i fugemasser og gulvmasser kreves laboratorieanalyse. Fuge- og gulvmasser fra perioden 1956-1973 skal undersøkes. Prøver bør tas på alle typer av fugemasser (respektive gulvmasser) i en bygning dvs alle masser som ser ulike ut. Det finnes et antall laboratorier som utfører slike analyser. En liste over aktuelle laboratorier finnes på den nevnte webplassen.

For isolerglassruter finnes noen eksempel på når man ved å identifisere merking på ruten kan avgjøre om de har forseglingslim med PCB eller ikke. I øvrige tilfeller betraktes svenske ruter fra 1956-1973 og importerte ruter frem til og med 1980 som PCB-holdige.

Også for småkondensatorer kan i visse tilfeller gi veiledning. Ellers skal installasjoner fra før 1980 anses som PCB-holdige.

\section{Kartlegging av PCB i Norge}

I Norge er situasjonen at prøver av fugemasser tas i begrenset grad og svært få prøver tas av maling og mørtel. Prøver tas i større grad av isolerglasslim og kondensatorolje, men det er etter hvert blitt innarbeidet en praksis at alle kondensatorer og isolerglassruter eldre enn 1980 leveres til mottak som om de inneholdt PCB. Det er vanlig at hele lysarmaturer leveres til godkjent mottak for elektrisk og elektronisk avfall og at kondensatorene demonteres der av praktiske årsaker. Både for kondensatorer og isolerglassruter har det dessuten vært en del usikkerhet rundt hvilke produksjonsår av de ulike produkter som må betraktes som PCB-holdige.

Veiledning om hvor de ulike forekomster av PCB normalt finnes $\mathrm{i}$ bygg og hvordan de kan kartlegges finnes i veilederen Identifisering av PCB i norske bygg ${ }^{45}$ som er utgitt av blant annet Byggenæringens Landsforening og Statens forurensningstilsyn. Det er for øvrig også etablert kurs både i generell miljøkartlegging av bygninger og identifisering og sanering av PCB.

\section{Kartlegging av PCB i Danmark}

Miljøstyrelsen har finansiert to kartlegginsprosjekter hvor mengdebestemmelse av PCB inngår:

- SBI, (udkast) 2005 «Sundhedsmæssig vurdering af PCB-holdige byggevarer»

- Arbejdsrapport: DEMEX, 2001: «Kortlægning af problematiske stoffer i bygge- og anlægsaffald»

- Miljøstyrelsen har envidere finansieret et projekt vedr. PCB i elektrisk udstyr:

- Arbejdsrapport nr. 15, 2000, COWI: «PCB i apparater i Danmark» 
Kartlegging av PCB i Finland

Kartlegging av PCB kreves kun i forbindelse med at fasaden (eller en annen bygningsdel) skal rives eller renoveres (Miljöministeriets rekommendationer, 2000) og gjelder fugemasser fra perioden 1959-1979. Kartleggingen samordnes med en inspeksjon av fasadens tekniske tilstand. I kartleggingen inngår som regel også asbest, bly, PAH-forurensninger og mikroorganismer.

Kartlegging av PCB på Island

På grunn av manglende kunnskaper om PCB i bygninger finnes det heller ingen konkrete planer om hvordan man skal kartlegge og håndtere PCB. Reykjavik kommune har imidlertid til hensikt å ta initiativet til kartlegging av PCB både i bygninger og i naturmiljøet.

\subsubsection{Kartleggings- og analysemetoder}

Kjemisk analyse i laboratorium

Det anvendes overordnet to metoder til analyse av PCB enten High Pressure Liquid Chromatography (HPLC) såkalt væskekromatografi eller gasskromatografi (GC). Felles for både væske- og gassmetoder er at de har en høy presisjon. De fleste laboratorier anvender en metode der man bestemmer mengden av de 7 vanligste PCB kongenene, av 209 teoretisk mulige. Ved å studere mønsteret hos disse 7 , kan man komme fram til hvilket PCB-produkt som er brukt.

Et norsk analyselaboratorium opplyser at det ved deres analysemetoder har en deteksjonsgrense på 0,5 ppm for PCB i fugemasse prøver og helt ned til 0,01 ppm for PCB i betongprøver. Måleusikkerheten ligger i intervallet ca. 15-20\%.

Pris for analyse av PCB-prøve er avhengig prøvens egenskaper og valg av laboratorium. Etter hvert som markedet har blitt større har analyseprisene blitt lavere og dette gjør at nødvendige analyser er mulig til overkommelige priser.

\section{Screeninganalyse}

Der man ønsker en rask indikasjon på om flytende prøver (oljer) inneholder PCB, kan man gjøre en screening av prøven på stedet. Prinsippet i screeningsmetoden er at man undersøker om prøven inneholder klor. Inneholder prøven klor, er det en indikasjon på at prøven inneholder PCB, og den bør sendes til nærmere analyse i laboratorium. Firmaet Norsk spesialolje NSO (og trolig flere) selger et apparat - nærmest en liten propanbrenner - og forbruksmateriell (kobbernett) som brukes til slik screening. 
PCB-hund

I Sverige finnes en hund som er trent opp til å finne PCB i bygninger. «PCB-hunder» gir imidlertid kun en indikasjon på innhold av PCB. En verifisering av det materialet hunden reagerer på krever analyse av materialprøve. At hunden ikke reagerer kan ikke nødvendigvis brukes som bevis til å kategorisere bygg eller bygningsmaterialer som PCB-frie. Bruk av «PCB-hund» kan være til stor hjelp om en større bygningsmasse eller bygninger med mange ulike fuger skal undersøkes. En enkelt hund kan undersøke opptil 40-50 rom på en dag. Prøvebiter kan også tas ut og legges på en nøytral plass der hunden kan undersøke dem.

Analyselaboratorier

En rekke laboratorier kan analysere prøver for innhold av PCB. De fleste laboratorier er sertifisert for analyse av noen prøvematerialer, men utfører som regel analyse av alle materialer. Det er ikke alltid nødvendig å få sertifiserte analyseresultater, og dette må derfor vurderes fra bygg til bygg.

\subsubsection{Saneringsmetoder}

Den tekniske utvikling har kommet langt når det gjelder metoder, verktøy og verneutstyr for sanering av PCB i bygg. Spesielt ved sanering av PCBholdige fugemasser, maling og murverk er utfordringene store og det har vært arbeidet først og fremst i Sverige, Norge og Finland med utvikling og utprøving av metoder og utstyr.

\section{Saneringsmetoder i Sverige}

I Sverige har bare arbeidsmetoder for fugesanering blitt studert nærmere og ledet frem til allmenne anbefalinger. Arbeidsmetodene er håndtverksmessige, tunge og tidkrevende og dermed kostnadskrevende.

Metoden som anvendes ved fugesanering er oftest utskjæring av fugemassen - i de fleste tilfeller med oscillerende (vibrerende) kniv - og deretter sliping av fugekantene. Sliping utføres med vinkelsliper (med slipeskive) eller rettsliper (med slipestift), avhengig av hvor vanskelig det er å komme til fugen. I visse tilfeller kan fugemassen i stedet tas bort gjennom saging i fugekanten, da fugemasse og forurenset materiale $\mathrm{i}$ fugekanten fjernes i en operasjon. Ved alle disse arbeidene anvendes en kraftig støvsuger for å samle opp støvet og hindre spredning av PCB til omgivelsene.

\section{Saneringsmetoder i Norge}

I Norge finnes beskrivelser/veiledninger for alle kjente forekomster av PCB. 
Fremgangsmåte ved sanering av PCB-holdige isolerglassruter er beskrevet i veilederen Identifisering av PCB i norske bygg ${ }^{45}$, på www.pcb.no og i faktaark utgitt av Statens forurensningstilsyn. Beskrivelsene legger vekt på vernetiltak for å sikre at saneringspersonell ikke blir skadet eller eksponert for PCB.

Fremgangsmåte for sanering av PCB-holdige kondensatorer er beskrevet i veilederen Identifisering av PCB i norske bygg ${ }^{45}$ og på www.renas.no.

Fremgangsmåte for sanering av PCB-holdig fugemasse, maling og mørtel er beskrevet i kurshefter til kurset «Sanering av PCB og arbeidsmiljø». En kort sammenfatning av dette prosjektet gis i det følgende:

Sanering av PCB-holdig maling kan foregå ved høytrykkspyling evt. i kombinasjon med malingsfjerner (kjemikaler) eller ved blastring, pigging, meisling og lignende. Ved bruk av vann og evt. kjemikalier bygges gjerne fasadene inn med stillaser og presenninger som sørger for at vann og fjernet maling/murpuss ikke spres til omgivelsene, men samles opp for rensing og håndtering som avfall. Ved bruk av såkalte tørre saneringsmetoder som blastring, pigging, meisling og lignende må det settes i verk tiltak for å samle opp støv og nedfall fra fjerningen og hindre spredning til omgivelsene. Sandblåsing anbefales ikke som metode, da det genereres mye støv som må samles opp ved omfattende rengjøring av stillaser og lignende. Det finnes også muligheter for å rive bygninger uten å fjerne den PCB-holdige malingen først. Det må da sørges for god kontroll med støv/småpartikler og PCB-forurensede masser må disponeres iht gjeldende regelverk.

Saneringsmetode for materialer med PCB-holdig mørteltilsetning, f.eks. murpuss, avrettingsmasser eller betonglim, vil avhenge av det konkrete tilfellet. Oftest vil murpuss/avrettingsmasse kunne fjernes ved fresing, meisling eller pigging. Materialene saneres med relativt normale rivemetoder, men det kreves ekstra innsats for å hindre spredning av støv. Arbeid som kan frigjøre PCB-holdig støv krever særskilte vernetiltak for å hindre at saneringspersonellet eksponeres for PCB.

Veiledningen for sanering av PCB-holdig fugemasse bygger i stor grad på veiledningen fra den Svenska Fogbranchens Riksförbund ${ }^{23}$.

Kurs holdes flere steder rundt $\mathrm{i}$ landet og egner seg primært for alle som arbeider med eller ønsker å arbeide med sanering av PCB i bygninger, men også for de som generelt har behov for mer kunnskaper om PCB og saneringsmetoder knyttet til sitt arbeide. Kursene holdes av Fellesforbundet i nært samarbeid med Byggenæringens Landsforening.

Saneringsmetoder i Danmark

Det er ikke utarbeidet spesielle krav til saneringsmetoder. 


\section{Saneringsmetoder i Finland}

Saneringsmetoder har blitt undersøkt under forskning ved Tammerfors regioninstitut för arbetshygien år 1999-2000. Metoder for fugesanering er utviklet likedan som i Sverige ${ }^{87}$.

Saneringsmetoder på Island

Saneringsmetoder vil bli utviklet basert på kartlegging av mengder og omfang av PCB i bygninger og fremtidige planer for sanering, ref kapittel 3.4.1.

\subsubsection{Sluttdisponering av PCB}

Destruksjon av PCB krever svært avanserte og kostbare forbrenningsanlegg med høy grad av røykgassrensing. Det er få slike behandlingsanlegg for PCB-holdig avfall og i mange tilfeller må derfor avfallet eksporteres. I Norden er det i dag bare SAKAB i Sverige, Ekokem i Finland og

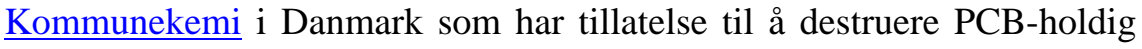
avfall.

\subsection{PCB i innemiljøet}

PCB kan påvirke innemiljøet i bygninger og det er derfor gjort undersøkelser i flere land for å kartlegge om dette kan ha negative helseeffekter for beboere og brukere av bygningene. Ingen av de nordiske land har normer eller grenseverdier for PCB i luft i boliger.

I Tyskland har man satt en grense for når det bør gjennomføres tiltak for å redusere PCB-nivået i inneluft - 3000 nanogram PCB per kubikkmeter luft $\left(\mathrm{ng} / \mathrm{m}^{3}\right) .300 \mathrm{ng} / \mathrm{m}^{3}$ anses for å være en akseptabel konsentrasjon i inneluft.

I Sverige har PCB-innholdet i luft blitt undersøkt i noen prosjekt. Sveriges Provnings- och Forskningsinstitut (SP) målte konsentrasjoner på ca $500 \mathrm{ng} / \mathrm{m}^{3}$ før sanering av fugemasser i fasade (to målinger) og ca 800 $\mathrm{ng} / \mathrm{m}^{3}$ etter sanering (en måling), nærmere beskrevet i SP rapport 1999:07 ${ }^{21}$.

Miljöförvaltningen i Stockholm har gjort en kartlegging av PCB i inneluft i et antall leiligheter og andre lokaler i Stockholm. Konsentrasjonene som ble funnet ved aktiv prøvetaking ligger alle under $300 \mathrm{ng} / \mathrm{m}^{3}$. Se rapporten «PCB i inomhusmiljön», Miljöförvaltningen i Stockholm, $2001^{20}$.

Niklas Johansson (Naturvårdsverket og IMM ved Karolinska Institutet) har gjort en tilsvarende studie av inneluft i hus med PCB-holdig fugemasse i fasade og hus av samme type uten PCB. I huset med PCBholdige fugemasser ble det registrert opp til 100 ganger høyere totalinnhold av PCB i luften enn i det andre huset. Middelverdien var mellom 5 og $350 \mathrm{ng} / \mathrm{m}^{3}$. Først og fremst fant man lavklorerte PCBer. Et forhøyet 
innhold i blodet hos dem som bodde i hus med PCB kunne også konstateres. Rapporten fra studien er ennå ikke publisert.

I Norge er eneste kjente undersøkelse av PCB i innemiljø (luft) i bygninger er en undersøkelse som ble utført av Folkehelseinstituttet i samarbeid med Statens forurensningstilsyn og Norsk institutt for luftforskning (NILU) i 1999. Det ble foretatt en begrenset undersøkelse av PCB i inneluft i utvalgte boliger der det med stor sannsynlighet ble benyttet større mengder PCB-holdig mørteltilsetning. Målingene, som ble utført av NILU, ble foretatt i de rommene der de største mengdene skulle ha blitt brukt. Målingene viste en del variasjon i PCB-nivåer mellom ulike boliger (fra 6 til 429 nanogram PCB per kubikkmeter luft). Dette er vesentlig lavere enn den tyske tiltaksgrensen. På bakgrunn av undersøkelsen anser ikke Folkehelseinstituttet det som et helseproblem å ha PCB-holdig murverk i bygninger.

\subsection{Arbeidsmiljø ved sanering av PCB}

Viktige faktorer som er sentrale for arbeidsmiljøet ved sanering av PCB kan være hudkontakt, luftkvalitet (støv og gasser), støy, vibrasjoner og ergonomi. I Sverige, Finland og Norge er det gjort studier og vurderinger av arbeidsmiljøet til de personer som sanerer PCB i bygninger. Arbeidsmiljømyndighetene har samarbeidet med bransjen om arbeidsmiljøkrav og tilsyn/kontroll.

Tabell 9. Normer/grenseverdier for PCB i arbeidsatmosfære i de nordiske land.

\begin{tabular}{|l|l|l|l|l|}
\hline Sverige & Danmark & Finland & Norge & Island \\
\hline $10 \mu \mathrm{g} / \mathrm{m}^{3}$ & $10 \mu \mathrm{g} / \mathrm{m}^{3}(\mathrm{At}$ & $0,5 \mathrm{mg} / \mathrm{m}^{3}$ & $10 \mu \mathrm{g} / \mathrm{m}^{3}$ & $10 \mu \mathrm{g} / \mathrm{m}^{3}$ \\
$(8$ timers & grenseverdi, jf. & $(8$ timers & $(8$ timers & $(8$ timers \\
periode $)$ & veiledning: C01 & $\begin{array}{l}\text { periode }) \\
1,5 \mathrm{mg} / \mathrm{m}^{3}\end{array}$ & periode $)$ & periode $)$ \\
& april 2005) & $\begin{array}{l}\text { (15 minutters } \\
\text { periode })\end{array}$ & & \\
& & & \\
\hline
\end{tabular}

\section{Sverige}

Sanering av fugemasser med PCB er et tungt og tidkrevende arbeid. Mye av arbeidet utføres over skulderhøyde og under knehøyde, noe som er ekstra belastende på kroppen. Fortsatt arbeid med utvikling av verktøy og metoder behøves, bl.a. avlastende hjelpemiddel for de ofte tunge håndholdte maskinene. Også vibrasjoner er et problem, men avvibrerende håndtak kan anvendes på maskinene. Det finnes også vibrasjonsdempende hansker. Maskinene bråker og hørselsvern er påkrevd. Et annet viktig arbeidsmiljøspørsmål er innholdet av PCB og støv i innåndingsluften. I Sverige er nylig kravene til støv skjerpet - grenseverdien er (fra 1. 
oktober 2005) $10 \mathrm{mg} / \mathrm{m}^{3}$ for inhalerbart støv. Grenseverdien for PCB i innåndingsluften er $10 \mu \mathrm{g} / \mathrm{m}^{3}$.

Anders Seldén ved Yrkes- og miljömedicinska kliniken, Universitetssjukhuset i Örebro, har gjort en studie av PCB-innholdet i blodet hos fugesanere. Etter et knapt år kunne ikke noen sikker økning av innholdet i blodet fastsettes. Dette tyder på at arbeiderne var bevisste på risikoen for eksponering av PCB og beskyttet seg derfor godt under arbeidet.

\section{Norge}

Det er ikke kjent at det er gjort fysiske eller kjemiske undersøkelser av arbeidsmiljøet for de som utfører sanering av PCB-holdig materiale i Norge. I prosjektet «PCB og arbeidsmiljø i bygg» i regi av Byggenæringens Landsforening og Fellesforbundet ble det ikke gjort fysiske målinger, men studier og vurderinger av arbeidsmiljøet ved sanering av fuger, maling og mørtel generelt. Hudkontakt, luftforurensning, støy, vibrasjoner og ergonomi ble vurdert i samråd med Statens forurensningstilsyn, Arbeidstilsynet, Folkehelseinstituttet og Statens Arbeidsmiljøinstitiutt og det ble utarbeidet veiledere for ivaretakelse av arbeidsmiljøet ved sanering av PCB.

Danmark

I Danmark har det i 1989 og senest i 2001 blitt gjennomført prosjekter med henblikk på kartlegging av hvor mye PCB som finnes i bygninger. Det pågår også og skal snart avsluttes ett prosjekt med tittelen «Sundhedsmæssig vurdering af PCB-holdige byggevarer». Medvirkende er Lars Gunnarsen, SBI, $\mathrm{m}$ fl.

Finland

Finland har en vesentlig høyere normverdi enn de øvrige nordiske landene. Finlands normverdi for arbeidsatmosfære ligger likevel innenfor intervallet av normverdier på $0,1-1,0 \mathrm{mg} / \mathrm{m}^{3}$ for øvrige europeiske land som England, Nederland, Tyskland og Sveits.

\subsection{Spredning av PCB fra bygninger til omgivelsene}

PCB i bygninger kan medføre spredning av PCB til omgivelsene rundt bygningene, først og fremst bygninger der det er anvendt PCB-holdig fugemasse, maling eller mørtel i fasadene.

\section{Sverige}

Bakgrunnen til at byggenæringen i Sverige startet arbeidet med PCB var opplysningene i en rapport fra Naturvårdsverket om at PCB lekker ut fra fugemasser i fasader til omkringliggende jord og luft ${ }^{18}$. Helt inntil 500 meter fra bygningen ble det målt PCB med samme mønster som i fuge- 
massen. Innholdet i luft var ved varmt vær sterkt forhøyet sammenlignet med bakgrunnsnivåene, men innholdet varierte sterkt mellom to tilfeller av prøvetaking. Utover denne studien finnes andre rapporterte undersøkelser av PCB-innholdet i jord, f.eks. utført av Golder Grundteknik $1998{ }^{16,17 .}$

\section{Norge}

Norges geologiske undersøkelse (NGU) har undersøkt innholdet av polyklorerte bifenyler (PCB) i husfasader (maling, puss og betong) og overflatejord i Oslo, Bergen, Trondheim og Tromsø. Det er påvist høye konsentrasjoner av PCB i ytterveggene på bygg fra 1950-1980. Overflatejorden rundt «PCB-bygg» er til dels sterkt forurenset med PCB. Høyest konsentrasjon opptrer fra 0-3 meter fra husveggen. PCB forurenset overflatejord kan påvises flere 100 meter fra bygningene. Det er påvist spredning av PCB fra husfasader til jord og videre til det marine miljøet. Dette er de eneste kjente undersøkelsene av spredning av PCB fra bygninger i omgivelsene i Norge. Se referanser til rapporter i kapittel 6.

Utendørs maling og mørtel forvitrer lett i vårt klima. En PCB-holdig fasade er derfor en aktiv forurensningskilde til det lokale utemiljø. NGUs prosjekter påviser en klar sammenheng mellom PCB-innhold i husfasader og innholdet i overflatejord inntil bygningene. I enkelte andre tilfeller vil PCB-typen i jorden ha en noe annerledes profil. Dette kan skyldes at jorden rundt bygningen er tilkjørt fra et annet sted, eller at det kan ha forekommet en viss nedbrytning av PCB-molekyler i jorden.

PCB-holdige fasader og omliggende jord er sannsynligvis viktige aktive kilder til forurensning i våre havner og fjorder. Undersøkelser som NGU utfører i samarbeid med Bergen kommune viser en klar sammenheng mellom aktive PCB-kilder på land og de mengder og typer PCB som finnes i havnesedimentene.

Forskjellige typer av eldre maling kan inneholde PCB. Omfanget i bruk av slik maling er ikke godt nok kjent. PVA-mørtel kan inneholde betydelige mengder PCB. Det er klare geografiske forskjeller i bruk av slik mørtel. Kun en liten andel av betong er forurenset med PCB. Husfasader med PCB-holdig maling og puss er viktige aktive forurensningskilder i vårt miljø.

Danmark

Statens Byggeforskningsinstitut (SBI) arbeider p.t. med en undersøkelse for Miljøstyrelsen, som inkluderer kartlegging av spredning til omkringliggende jord.

Finland

Man har i Finland gjort undersøkelser av PCB forurensninger i jorden rundt bygninger og det er dokumentert at PCB har spredt seg til jorden i mange tilfeller ${ }^{73,80,86}$. Det er påvist at PCB lekker ut fra fugemassene til jorden og at konsentrasjonen av PCB er høyest nærmest bygningene. Med 
utgangspunkt i undesøkelsene ${ }^{73,80,}$ er det gjort risikovurderinger av eventuelle helseeffekter.

Miljöministeriet har publisert anbefalinger om tiltak på for jord som har blitt forurenset med PCB ${ }^{83}$. Helserisikoen er lav, men risikoen for spredning må tas hensyn til ved hagearbeid og ved utgravning. PCBproblemet aktualiseres ofte i forbindelse med at dreneringen skal legges om. Anbefalinger er utarbeidet basert på forskning om PCB-innholdet og helserisiko i utemiljöet ${ }^{73,80}$.

Anbefalingene er at det ikke plantes spiselige planter nær ytterveggene og at barns lekeplasser flyttes lenger bort fra ytterveggene.

Island

På Island vil kartlegging av PCB spredt i omgivelsene blir innarbeidet i fremtidige planer for kartlegging og håndtering av PCB i bygninger og naturmiljøet.

\subsection{Avfallshåndtering}

\subsubsection{Grenseverdier for PCB-holdig avfall}

Hvordan PCB-holdig avfall skal håndteres er avhengig av innholdet av PCB. Tabell 10 gir en oversikt over de gjeldene grenseverdier for PCBholdig avfall i de ulike land. 
Tabell 10. Grenseverdier for disponering av PCB-holdig avfall fra bygg.

\begin{tabular}{|c|c|c|c|}
\hline & Farlig avfall & $\begin{array}{l}\text { Rene materialer, } \\
\text { mest følsom arealbruk }\end{array}$ & Andre grenseverdier \\
\hline SE & $\begin{array}{l}\text { Totalinnhold > } 50 \mathrm{mg} / \mathrm{kg} \text { er pr i } \\
\text { dag alltid farlig avfall, men kan } \\
\text { også være det ved lavere } \\
\text { innhold av PCB. Den lokale } \\
\text { tilsynsmyndigheten avgjør i } \\
\text { hvert enkelt tilfelle. Dette } \\
\text { endres trolig i den nye forord- } \\
\text { ningen. }\end{array}$ & $\begin{array}{l}\Sigma 7 \mathrm{PCB}<0,02 \mathrm{mg} / \mathrm{kg} \\
\text { TS } \\
\text { TS= tørrstoff } \\
\text { Normverdi for følsom }_{\text {arealbruk }^{1}}\end{array}$ & $\begin{array}{l}\text { Tillatt PCB-innhold i avfall til } \\
\text { deponi. } \\
\text { Deponi for inert avfall får ta } \\
\text { imot avfall med } \Sigma 7 P C B<1 \\
\mathrm{mg} / \mathrm{kg} \text {, deponi for ikke-farlig } \\
\text { avfall } 1-50 \mathrm{mg} / \mathrm{kg} \text { og deponi for } \\
\text { farlig avfall }>50 \mathrm{mg} / \mathrm{kg} \text {. }\end{array}$ \\
\hline$\frac{5}{50}$ & $\Sigma 7 \mathrm{PCB}>50 \mathrm{mg} / \mathrm{kg}$ & $\begin{array}{l}\Sigma 7 P C B<0,01 \mathrm{mg} / \mathrm{kg} \\
\text { Anbefalt normverdi for } \\
\text { mest følsom arealbruk }\end{array}$ & $\begin{array}{l}\text { Hvis } \Sigma 7 \text { PCB } \\
\text { er mellom } 0,01 \text { og } 50 \mathrm{mg} / \mathrm{kg} \text {, } \\
\text { kan avfallet leveres til deponi } \\
\text { med tillatelse opp til en gitt } \\
\text { grenseverdi, som oftest inntil } \\
0,1-10 \mathrm{mg} / \mathrm{kg} \text { (varierer) } \\
\end{array}$ \\
\hline DK & $\Sigma 7 P C B>50 \mathrm{mg} / \mathrm{kg}$ & Ingen grenseverdi & \\
\hline FIN & TotalPCB > 50mg $/ \mathrm{kg}$ & Ingen grenseverdi & \\
\hline $\begin{array}{l}\square \\
\square \\
\text { IS }\end{array}$ & $\Sigma 7 \mathrm{PCB}>50 \mathrm{mg} / \mathrm{kg}$ & Ingen grenseverdi & \\
\hline
\end{tabular}

Dessverre finnes det ikke noen internasjonal konsensus om hvordan man skal måle PCB-innholdet. Dette innebærer at ulike nasjonale og internasjonale regelverk angir ulike metoder

Det bemerkes til tabell 10 at regelverket i Sverige, Finland og EU forholder seg til totalt innhold av PCB, mens regelverket i Norge, Danmark og Island forholder seg til de 7 vanligste PCB-kongenene, av 209 teoretisk mulige, dvs Sum7PCB eller 57 PCB. 57 PCB vil kunne være fra 3 til 8,2 ganger lavere enn Total PCB. I Norge er $\Sigma 7 \mathrm{PCB}$ valgt som referanseenhet ut fra praktiske hensyn, siden forskjellene i de fleste tilfeller ikke vil ha betydning for om et materiale er farlig avfall eller ikke. Når det gjelder normverdi for mest følsom arealbruk (Norge og Sverige) er referanseenheten alltid $\Sigma 7 \mathrm{PCB}$.

Mye PCB kommer på avveie, enten i forbrenningsanlegg eller på avfallsdeponier fordi det ikke er tilstrekkelig kartlagt. Særlig stor er risikoen for at tyngre bygningsmaterialer som betong og tegl inneholder PCB i

\footnotetext{
${ }^{1}$ Grenseverdi finnes ikke, men Naturvårdsverket har formulert en normverdi for følsom arealbruk, $\Sigma 7$ PCB høyst ca 0,02 mg/kg TS. En undersøkelse av spredning av PCB fra fugemasser til tilgrensende materiale anbefaler at fugekanter fjernes slik at restmaterialet i gjennomsnitt innehnolder $\Sigma 7 P C B$ mindre enn ca $0,02 \mathrm{mg} / \mathrm{kg}$ TS. Verdien overensstemmer med Naturvårdsverkets normverdi for følsom arealbruk ${ }^{19}$.
} 
maling, mørtel eller rester av fugemasse når det knuses og anvendes til blant annet oppfyllingsformål.

\subsubsection{Behandlingsanlegg}

I Norge finnes to behandlingsanlegg for PCB-holdige isolerglassruter. Disse to anleggene mottar kasserte isolerglassruter fra hele landet via retursystemet til Ruteretur AS. Disse behandlingsanleggene har kompetanse og utstyr til å separere de PCB-forurensede komponentene i isolerglassrutene fra de gjenvinnbare (tre, glass, metaller). Fraseparerte PCBholdige materialer sendes til destruksjon, mens de øvrige materialene gjenvinnes.

For sluttdisponering (destruksjon) av PCB-holdig avfall som er farlig avfall vises det til kapittel 3.4.4.

For sluttdisponering av PCB-holdig avfall som ikke er farlig avfall ( $<50 \mathrm{mg} / \mathrm{kg}$ ) er regelverket ofte uklart. I utgangspunktet kan slikt avfall betraktes som ordinært avfall, men avfallsdeponier og forbrenningsanlegg har ofte begrensninger i sine tillatelser til hva de har lov å ta imot. Størst problem er dette i forbindelse med PCB-forurensede tyngre rivemasser som betong og murverk, se kapittel 3.8.3.

\subsubsection{Gjenvinning av PCB-holdig rivemateriale}

PCB i betong og murverk setter begrensninger for gjenvinning av disse materialene. I betong og murverk kan kildene til PCB-forurensning være rester av fugemasse, maling, mørteltilsetning, lekkasje av transformatorolje eller lignende. Graden av forurensning og arealbruk avgjør om disse materialene kan gjenvinnes eller ikke, jf grenseverdier i kapittel 3.8.1. Det er viktig å merke seg at materialer som ut fra en vurdering av lavt eller ikke noe PCB-innhold synes å være egnet for gjenvinning, ikke nødvendigvis er det. Materialene kan inneholde andre miljøfarlige stoffer som overstiger grenseverdiene for fri disponering, for eksempel kan rivematerialene inneholde olje, PAH eller tungmetaller.

Av de nordiske landene har trolig Norge kommet lengst i å utvikle regelverk og standarder for gjenvinning av rivematerialer som betong og murverk. For at disponeringen av rivematerialer skal kunne betraktes som gjenvinning, setter norske myndigheter følgende betingelser:

- Materialegenskapene blir utnyttet

- Materialet tilfredsstiller gitte egenskaper

- Mottaker har bruk for materialet

- Materialet er rent nok

Statens forurensningstilsyn (SFT) har utarbeidet et faktaark om disponering av rene naturlige masser og gjenvunnet materiale ${ }^{52}$, som angir hvilke 
krav som stilles for at et materiale skal kunne betraktes som rent. I tillegg til dette anvendes veiledningen SFT 99:01 A ${ }^{47}$ Risikovurdering av forurenset grunn til å vurdere om et materiale er rent nok til ulike typer arealbruk. Her er det normverdien $\Sigma 7 \mathrm{PCB}=0,01 \mathrm{mg} / \mathrm{kg}$ som anvendes for å vurdere om materialet er rent nok for mest følsom arealbruk.

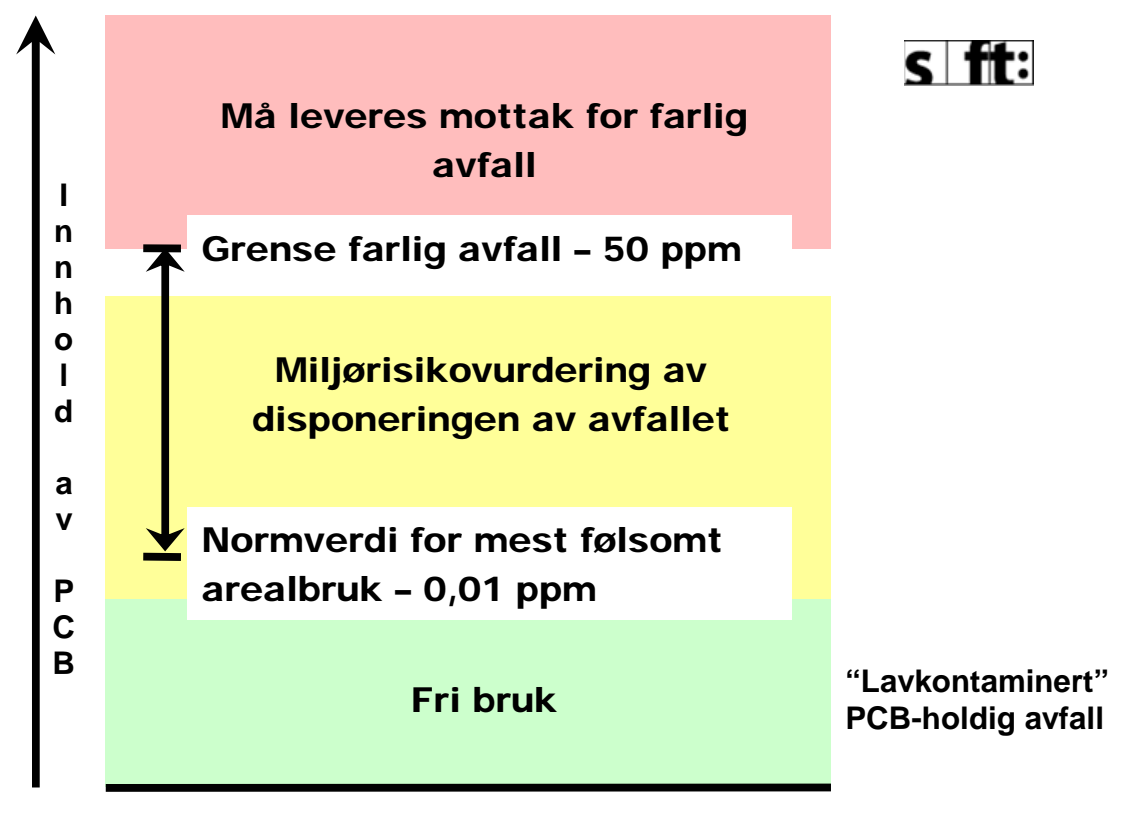

Figur 1. Praktisering av norm-/grenseverdier for PCB $i$ norsk regelverk (verdier $i$ Sum7PCB).

Dersom det er ønskelig å benytte PCB-forurenset rivemateriale til for eksempel oppfyllingsformål, kan det gjøres en miljørisikovurdering etter $\underline{\text { SFT 99:01 A }}{ }^{47}$ og avhengig av bruksområde må miljømyndigheten søkes om tillatelse til slik bruk.

Prosjektene Gjenbruksprosjektet og RESIBA omhandler blant annet miljørisikovurdering ved gjenvinning av rivematerialer i vegbygging og andre bygg- og anleggsformål. Prosjektene har utarbeidet standarder for deklarasjon og kvalitetskontroll av rivematerialer som skal anvendes til nye formål ${ }^{58}$. Norges geologiske undersøkelse (NGU) har gjennom kartlegging av PCB-forurensning i bygningsmassene og jordsmonnet rundt bygningene utredet hva som er beste form for anvendelse av PCBforurensede rivematerialer og forurenset jord ${ }^{54}$.

\subsubsection{Transport av PCB-holdig avfall}

PCB-holdig avfall omfattes i hele Europa av regelverket for transport av farlig gods.

Hvert lovverk om transport har sine egne bestemmelser i form av et regelverk. Regelverket har alle sitt opphav i FN-anbefalingene for trans- 
port av farlig gods slik at de har mange likheter. De ulike regelverkene oppdateres og endres med jevne mellomrom og det er viktig å alltid ha tillgang til den gjeldende utgaven.

Følgende regelverk er tilgjengelige for de ulike transportlovverk:

\section{Vegtransport}

ADR/ADR-X gjelder for internasjonal respektive nasjonal transport av farlig gods på veg og i terreng. Bokstaven "X» står for det respektive lands utgave.

\section{Jernbanetransport}

RID/RID-X gjelder for internasjonal respektive nasjonal transport av farlig gods på jernbane. Bokstaven «X» står for de respektive lands utgave.

Regelverket tilpasses noe ulikt i de forskjellige land, men alle har lagt den internasjonale avtalen om veg-/jernbanetransport av farlig gods (ADR/RID) til grunn.

Svensk transportregelverk

Avfall med PCB er farlig avfall og håndteres i henhold til avfallsforordningen (2001:1063). Den foreskriver at journal skal føres om mengde og type av avfall og hvor det transporteres. Transport av avfall med PCB krever at transportøren og mottakeren har tillatelse fra länsstyrelsen. Også for mellomlagring av dette avfallet kreves tillatelse fra länsstyrelsen. Transport av PCB-avfall skal også følge reglene for transport av farlig gods. Det kreves i prinsipp ADR-godkjenning uansett mengde som transporteres så lenge innholdet av TotalPCB er over $50 \mathrm{mg} / \mathrm{kg}$.

Norsk transportregelverk

Transport av PCB og annet farlig gods reguleres gjennom Forskrift om landtransport av farlig gods. Ved transport av inntil $500 \mathrm{~kg}$ netto farlig avfall definert som farlig gods gjelder kun bestemmelsene i ADR og RID om krav til godkjent emballasje, merking, samemballering og transportdokumentasjon. Ved mengder over $500 \mathrm{~kg}$ netto farlig gods gjelder alle bestemmelser i ADR og RID.

Dansk transportregelverk

I Danmark kreves godkjennelse som transportør av avfall. Avfall med PCB anses som farlig avfall og krever spesiell klassifisering og forhåndsanmeldelse. Kommunen er pliktig til å anvise avfallet til rett sted.

Finsk transportregelverk

PCB-avfall skal transporteres som farlig gods. Det kreves ADRgodkjenning uansett mengde som transporteres så lenge innholdet av TotalPCB er over $50 \mathrm{mg} / \mathrm{kg}$. 
Islandsk transportregelverk

Det islandske transportregelverk har pr i dag ikke spesielle krav mht PCB, men blir stadig mer aktuelt siden et islandsk avfallsforbenningsanlegg nå kan ta i mot og behandle PCB-holdig olje.

\subsection{Forskning og utvikling}

PCB i bygninger er et relativt nytt fagområde og behovet for forskning og utvikling er stort. I det følgende presenteres eksempler på hva som er gjennomført i de ulike land.

I Sverige er det gjennomført FoU-prosjekt av ulike slag om spredning fra fugemasser til omkringliggende miljø og luft, til innemiljø og til tilgrensende materiale, samt visse anbefalinger om gjenvinning av materiale f.eks. for vegunderbygning. Metoder for sanering har blitt utviklet av bransjen selv. Undersøkelser er gjort av arbeideres opptak av PCB i blodet, av PCB i luft i arbeidsmiljøet og av PCB i luft i boliger der PCBholdige fugemasser eller gulvmasser finnes. Disse studier er tidligere beskrevet i de ulike kapittel.

I Norge er det gjort studier i forhold til både kartleggingsmetoder og saneringsmetoder for PCB i bygninger og arbeidsmiljø i denne forbindelse. Norges Geologiske Undersøkelse (NGU) har som nevnt i kapittel 3.7 utført en rekke undersøkelser av sammenhengen mellom PCB i maling og murpuss i fasader og forurenset jord rundt bygningene. Også forurensede sedimenter i fjorder er i denne forbindelse kartlagt. I Gjenbruksprosjektet og RESIBA-prosjektet er det utført miljørisikovurderinger og utlekkingstestet med hensyn til PCB i resirkulert btong og tegl som anvendes i veibygging og lignende, ref. kapittel 3.8.3.

I Finland er det gjort undersøkelser først og fremst med hensyn til PCB-holdige fuger og PCB-forurenset jord. PCB i maling undersøkes av det tekniske universitetet i Tammerfors. I Finland er det også arbeidet en del med saneringsmetoder og arbeidsmiljø ved sanering av PCB holdige fuger.

I Danmark har Statens byggeforskningsinstitut og Golder Associates gjennomført undersøkelser av PCB i danske bygninger og i avfall fra nedrivning og renovering, et prosjekt finansiert av Miljøstyrelsen. København kommune har iverksatt egne undersøkelser for å kartlegge utbredelsen av PCB i københavnske bygninger.

På Island håper man at dette nordiske prosjektet skal være en start på arbeidet med å undersøke omfanget av PCB i bygninger og utarbeide en plan for hvordan dette skal håndteres i tiden fremover. Spesielt anses det som interessant å finne ut om PCB er benyttet i maling på fasader på tilsvarende måte som i norske kystområder.

Det vises for øvrig til litteraturlisten i kapittel 6. For mer informasjon om utførte og pågående FoU-prosjekter i nordiske land. 



\section{Slutsatser}

\subsection{Inledning}

Ett av de viktigaste syftena med projektet har varit att identifiera gemensamma utmaningar i arbetet med att sanera PCB i de nordiska länderna. I detta kapitel redovisar vi slutsatserna av seminariet i Oslo den 7-8. mars 2005 och den vidareutveckling av slutsatserna som rapportförfattarna gjort. Förslag till hur utmaningarna skall mötas finns i kapitel 5.

\section{2 "The cost of late action"}

I en rapport från Nordiska Ministerrådets Kemikaliegrupp "The cost of late action - the PCB-case” visar författarna på de stora vinsterna med att tidigt fasa ut miljöskadliga ämnen. Och då har man inte räknat på hälsoeffekterna på djur och människor. Kostnaderna för att sanera PCB i norden är mycket stora. Stora vinster finns således att göra på att så tidigt som möjligt indentifiera och fasa ut användningen av miljöskadliga ämnen.

Beträffande PCB är det emellertid viktigt att också se kostnaderna för den pågående användning av PCB i t.ex. byggtillämpningar - t.ex. fogmassor, golvmassor och färger. Kostnaderna för att sanera PCB som spritts i miljön är mycket höga, norska fjordar och svenska sjöar (t.ex. Järnsjön) är avskräckande exempel. I praktiken är det omöjligt att i efterhand samla in den PCB som läckt ut.

Slutsatsen av detta resonemang är att trots att kostnaderna för att sanera t.ex. PCB-haltiga fogmassor är höga så är det ändå väl motiverade kostnader i förhållande till att i efterhand åtgärda problemet. En viktig förutsättning är emellertid att saneringarna görs miljömässigt korrekt och att utsläppen vid saneringen minimeras.

\subsection{Olika perspektiv och prioriteringar i de nordiska länderna}

Det finns betydande skillnader i prioriteringar och synsätt mellan de nordiska länderna. Synsättet varierar främst beroende på om man ser PCB som ett miljö- eller hälsoproblem. När vi jämför hur de nordiska länderna har arbetat så har vi tidigare konstaterat att myndigheterna i de nordiska länderna valt att i första hand angripa de storskaliga industriella tillämp- 
ningarna av PCB. Här förefaller de nordiska länderna att ha nått väldigt långt. På denna konferens diskuterades inte alls resultatet av detta arbete.

Vid en jämförelse mellan de nordiska länderna så kan man konstatera följande skillnader mellan de nordiska länderna.

Det svenska synsättet har varit att PCB är både ett miljö- och ett hälsoproblem.

Den fortsatta politiska hanteringen av kravet på PCB-sanering har präglats av bristande engagemang och först 2006, efter mer än tre års försening väntas en förordning med krav på sanering av PCB-haltiga fogmassor att träda i kraft.

Bygg- och fastighetsbranschen har också svarat med egna initiativ när det gäller hantering av PCB i byggnader.

Det norska synsättet har varit att PCB är både ett miljö- och hälsoproblem. I Norge gjorde SFT under 1990-talet undersökningar av hur PCBproblemet inom bygg- och fastighetssektorn ser ut. Utifrån dessa undersökningar gjorde SFT bedömningar av hur de olika PCB-produkterna borde angripas och beträffande isolerrutor och småkondensatorer formulerade SFT tydliga program. SFT har hela tiden haft en operativ orientering och flitigt producerat råd och anvisningar.

Bygg- och fastighetsbranschen har svarat med egna initiativ när det gäller hantering av PCB-haltiga isolerrutor och PCB i småkondensatorer. Sedan år 2000 har merparten av information och kompetensutveckling skötts av branschen själv. Branschen har tagit fram vägldeningar för identifiering av PCB i byggnader ${ }^{45}$ och utvecklat en branschanpassad kurs för sanering av PCB i byggnader. Byggnadsarbetarfacket har medverkat till ett initiativ att höja kompetensen hos byggnadsarbetarna beträffande PCB.

I Danmark infördes som tidigare nämnts 1986 en bestämmelse om att byggavfall med mer än 0,005 viktsprocent PCB ska hanteras som farligt avfall. Miljöstyrelsen har också i brev till kommunerna vid två tillfällen pekat på problemet med PCB i byggavfall. I den praktiska hanteringen förefaller dock vare sig bygg- och fastighetsbranschen eller de lokala myndigheterna ägna PCB-problemet någon större uppmärksamhet.

I Finland har myndigheterna i huvudsak sett PCB som ett miljöproblem, inte ett hälsoproblem. De PCB-haltiga fogmassorna har man inte sett som något stort problem.

På Island förefaller inte problemet med PCB i byggnader särskilt väl känt vare sig på myndighetssidan eller inom bygg- och fastighetssektorn.

\subsection{Har Norden något att lära Europa och den övriga omvärlden?}

Det finns behov av att förstärka samarbetet på PCB-området mellan de nordiska länderna och att harmonisera det nordiska synsättet beträffande 
PCB i byggnader. De nordiska länderna, framförallt Norge och Sverige har kommit långt när det gäller att identifiera och ta om hand PCB i byggnader. Norden skulle kunna driva på det internationella arbetet med utfasningen av PCB i byggnader. Det gemensamma nordiska synsättet borde vara att

- PCB är både ett miljö- och hälsoproblem

- PCB ska saneras vid både rivning och underhåll/ombyggnad

Hanteringen av PCB i byggnader i Europa och den övriga omvärlden diskuterades inte särskilt djupt på seminariet men det förefaller vara så att de skillnader i synsätt som finns mellan de nordiska länderna finns i ännu högre grad internationellt. Det förefaller också utanför Norden vara så att man huvudsakligen prioriterar hälsoaspekten. I t.ex. Tyskland har man tidigt fokuserat på PCB i inomhusluft och det är i huvudsak de tyska gränsvärdena för PCB i inomhusluft som tillämpas i de nordiska länderna.

Det borde också finnas stora fördelar med att de nordiska länderna samordnar t.ex.

- Regelverken beträffande PCB

- Information om den mest utvecklade kunskapen och pågående projekt

- Teknisk utveckling beträffande t.ex. saneringsutrustning och saneringsteknik

\subsection{Det finns brister beträffande kunskap och kompetens om PCB}

Dagens kunskap om PCB har svårt att nå ut till sektorns aktörer. Inom bygg- och fastighetssektorn men också till stor del även hos de lokala myndigheterna finns en stor brist på kunskap och kompetens beträffande PCB.

Det finns också behov av att öka kunskapen om alla de olika användningar av PCB som har funnits inom bygg- och fastighetssektorn. De stora användningarna är relativt väl kända men hur stora mängder som använts och hur mycket som finns kvar är osäkert. De mindre tillämpningarna har inte kartlagts på något systematiskt sätt. Det kan t.ex. gälla PCB i murbruk och fasadfärger och om PCB har använts som mjukgörare i vissa mattyper och/eller lim och andra färger.

Kunskaperna beträffande spridning av PCB i miljön samt miljö- och hälsopåverkan av PCB är också fortfarande begränsade.

Det finns också en begränsad vilja att erkänna problemet. Kostnaderna för att sanera PCB är höga. Det finns fortfarande ett stort behov av att informera om PCB i byggnader. 


\subsection{Det finns behov av bättre miljöinventeringar och bättre rivnings- och avfallsplaner}

Ett stort miljöproblem är att PCB inte blir upptäckt innan rivningssarbetena börjar. I bästa fall hamnar PCB-avfallet på en godkänd deponi eller i en förbränningsanläggning och i värsta fall ute i naturen vid illegal eller okontrollerad deponering. Det finns behov av ordentliga avfallsinventeringar och planer för hur avfallet ska hanteras innan rivningen påbörjas.

Kraven på rivningsplaner/avfallsplaner tillämpas mycket olika i de olika nordiska länderna. Det finns även betydande skillnader både inom och mellan länderna. Det förefaller också i alla de nordiska länderna vara så att kontrollen av rivningsplaner och tillsynen vid rivningar i stort sett är obefintlig.

Kopplingen mellan bygglagstiftning och miljölagstiftning och mellan de myndigheter som ska tillämpa respektive lagstiftning förefaller vara bristfällig i alla de nordiska länderna.

\subsection{Kvaliteten på miljöinventeringarna är låg}

Kvaliteten på miljökartläggning/miljöinventering är låg. I dag saknas i stort sett i hela Norden standarder och kvalitetskrav på miljöinventeringar och kompetenskrav på miljöinventerare. Det behovet finns inte bara beträffande PCB. Det finns ett tydligt behov av att lyfta miljöinventerarnas yrkesmässiga status och att skapa något slags certifiering av miljöinventerare och standarder för hur miljöinventeringar skall göras och hur avrapporteringen ska se ut. Sannolikt är detta frågor som också bör hanteras på europanivå.

Kanske kan den svenska modellen med en standardiserad utbildning och en standard (CMF) för miljöinventerare vara en förebild. Den svenska modellen behöver emellertid vidareutvecklas.

\subsection{Brister beträffande rådgivning, tillsyn och kontroll från myndigheterna}

Seminariet visade också att det brister när det gäller rådgivning tillsyn och kontroll från myndigheterna i samtliga de nordiska länderna.

De centrala myndigheterna har en viktig roll när det gäller att vägleda både den lokala tillsynsmyndigheten (i regel kommunen) och inte minst de små företagen i bygg- och fastighetssektorn om hur en korrekt hantering av farliga ämnen/farligt avfall ska gå till och inte minst då hur man ska hantera PCB-avfallet. 
De små kommunerna förefaller påtagligt ofta lida av både kompetensoch resursbrist något som innebär att tillsynen från kommunen blir lidande. Sektorns aktörer vill många gånger ha en väl fungerande tillsyn från kommunen och kommunen som en samtalspartner.

De nordiska länderna består till stora delar av glesbygd med små kommuner och att en mycket stor andel av företagen i bygg- och fastighetssektorn är små. Både regelverk och rådgivning måste anpassas efter det förhållandet.

\subsection{Det finns kvalitetsbrister vid sanering av PCB}

De svenska erfarenheterna av PCB-sanering är att det finns kvalitetsbrister när det gäller saneringen av PCB-fogar. De branschanvisningar som finns följs inte alltid, kontrollen är bristfällig och det blir sällan några påföljder av att inte följa anvisningarna.

Det finns idag behov av standarder och kvalitetskrav beträffande PCB-sanering.

\subsection{Arbetsmiljön vid sanering av PCB behöver utvecklas}

Etter hvert som antallet arbeidsoperasjoner der man er i befatning med helse- og miljøfarlige stoffer blir stadig flere, øker også risikoen for å bli eksponert for stoffene og andre arbeidsmiljproblemer. De svenska erfarenheterna av sanering av PCB-fogar visar också att det finns stora problem med arbetsmiljön vid saneringen. Problemen är i huvudsak

- skydd mot inandning av PCB-haltigt damm och gaser

- skydd mot hudkontakt med PCB-haltigt damm

- vibrationer från handhållna verktyg

- ergonomi vid obekväma arbetsmoment

- obekväma och (sommartid) varma skyddskläder

Det finns både behov av bättre teknisk utrustning och anvisningar för hur saneringsarbetena skall utföras.

Finland har ett hygieniskt gränsvärde för PCB i arbetsmiljön som är 5 gånger högre än det som tillämpas i de övriga nordiska länderna. Det finska gränsvärdet ligger inom det intervall $0,1-1,0 \mathrm{mg} / \mathrm{m}^{3}$ som används i t.ex England, Tyskland och Schweitz. Det hade varit önskvärt att det finska gränsvärdet hade varit detsamma som det som tillämpas i de andra nordiska länderna. 


\subsection{PCB i innemiljön}

Det finns idag ett begränsat antal studier av hur hälsan för de boende i hus med PCB-fogar eller andra PCB-källor påverkas. Studier har framförallt gjorts i Sverige och Finland. Inget av de nordiska länderna har emellertid ställt upp normer för hur mycket PCB som kan tolereras i innemiljön och hur PCB i inomhusluft skall mätas. I regel hänvisar man till tidigare nämnda tyska normer.

Det finns behov av en standard för hur PCB i innemiljön ska mätas och vilka halter som kan accepteras.

\subsection{PCB i färger, putser och murade konstruktioner}

Kunskaperna om hur PCB har använts i färger, putser och murade konstruktioner är begränsade. Det är i första hand i Norge och Finland som man har gjort undersökningar inom detta område. Det kan finnas behov av att studera eventuella likheter mellan de norska och finska erfarenheterna. Det är okänt i vilken utsträckning PCB förekommer i färger, putser och murade konstruktioner i de övriga nordiska länderna.

I Norge är det känt att färger med PCB-innehåll har använts på fasader i särskilt väderutsatta områden (kyststrøk). Det skulle vara intressant att undersöka om sådana färger också har använts på Island som har samma liknande väderutsatta områden som Norge.

Källan till PCB i färger är inte alltid känd. Insamling av analysdata från Norge skulle kunna ge kunskap om varifrån den PCB som finns i färger, putser och murade konstruktioner kommer.

Det finns också behov av att utbyta erfarenheter om framförallt metoder för sanering av PCB i färger.

\subsection{Miljörisker vid återvinning av PCB-förorenade byggmaterial}

Återvinning av tunga byggmaterial som betong och tegel innebär en tydlig föroreningsrisk förutsatt att man inte genomfört en ordentliga avfallsinventeringar innan rivningen påbörjas.

Under årens lopp har troligen avsevärda mängder PCB-förorenat material blivit deponerat på både legala och illegala deponier. Eftersom miljökartläggning i många fall fortfarande inte görs och kontroll av rivningsmassor i stort sett är obefintlig så är det sannolikt att det även nu förekommer att rivningsmassor med PCB hamnar där de inte borde. Problemet är sannolikt likartat i alla de nordiska länderna.

Ett gemnsamt nordiskt problem är i det här sammanhanget är att regelverket är oklart när det gäller låghaltigt PCB-avfall. Det vil si avfall 
som innehåller en totalhalt $<50 \mathrm{mg} / \mathrm{kg}$. Det finns behov av klara riktlinjer för hur det låghaltiga avfallet ska kartläggas, kontrolleras och hanteras.

\subsection{Sanering av PCB-förorenad jord}

Problemet med PCB-föroreningar i marken intill byggnader där fasaderna innehåller eller har innehållit PCB-föroreningar har uppmärksammats i såväl Sverige och Finland som i Norge. Spridningen av PCB till sjöar, vattendrag och kustområden samt risken för att människor och framförallt då barn utsätts för PCB i närmiljön är en stor utmaning som bör uppmärksammas mera i alla de nordiska länderna. 



\section{Förslag}

\subsection{Inledning}

En av de viktigaste slutsatserna är att de nordiska länderna, främst då Norge och Sverige, har kommit långt i arbetet med att hantera PCB i byggnader och kan lämna väsentliga bidrag till det europeiska arbetet. I resten av Europa förefaller diskussionen att ännu inte ha kommit igång. De nordiska länderna skulle kunna bidra till att man inom EU ökar engageamanget beträffande PCB. En viktig förutsättning för detta är att de nordiska länderna har utvecklat ett samsyn på hanteringen av PCB i byggnader.

De stora utmaningarna är:

- Kunskapen om PCB och hur det ska hanteras är bristfällig bland branschaktörerna

- Viljan att erkänna problemet är begränsad. Det är dyrt att sanera PCB

- Det är svårt att nå ut med information

Seminariet och de efterföljande kontakterna under arbetet med rapporten har resulterat i ett antal förslag beträffande det fortsatta arbetet med PCB i byggnader. Rapportförfattarna har valt att rikta förslagen till PCBfrågans olika aktörer

- Regeringar, centrala myndigheter

- Tillsynsmyndigheter

- Miljökonsulter

- Fastighetsägare

- Saneringsföretag

- Verksamma inom forskning och utveckling

- Byggutbildningar

Det finns ett stort utrymme för nordiskt samarbete. I avsnitten nedan finns idéer och skisser till åtgärder. 


\subsection{Regeringar och centrala myndigheter}

\subsubsection{Gemensam nordisk syn på PCB i byggnader}

Miljöarbetet styrs idag i stor utsträckning av olika EU-direktiv. Tillämpningen av direktiven varierar kraftigt inom Europa. Detta gäller inte minst när det gäller PCB i byggnader. Det förefaller främst vara i Norden som det pågår ett organiserat arbete inom detta område. Mellan de nordiska länderna finns det här i ett samsyn beträffande gränsvärden, beräkningsmetoder $\mathrm{mm}$, men det finns betydande skillnader i synen på PCBproblemet. Enligt författarnas mening bör grunden vara att de nordiska länderna ser PCB som både ett miljö- och hälsoproblem.

\subsubsection{Gemensam nordisk strategi beträffande PCB i byggnader och byggavfall}

De nordiska länderna bör kunna samlas kring en gemensam strategi för PCB i byggnader och byggavfall. Även om omfattningen på problemet varierar mellan länderna så finns det många gemensamma faktorer, som t.ex. i allt väsentligt likartad byggteknik, många små resurssvaga kommuner och gles bebyggelse.

En gemensam strategi borde vara att så tidigt som möjligt angripa källan för att minimera spridningen av PCB i miljön för att därigenom minska både miljö och hälsorisker. En sådan strategi ställer krav på alla involverade myndigheter och branschaktörer:

- Höj kompetensen beträffande PCB hos både myndigheter och branschaktörer för att säkerställa en korrekt hantering av PCB.

- Säkerställ att det finns lättillgänglig information beträffande PCB

- Förbättra myndighetstillsynen både vid saneringsarbete och hantering av bygg- och rivningsavfall

- Skapa positiva incitament t.ex. genom att som i Norge rabattera kostnaderna för de fastighetsägare som sanerar PCB.

- Inom ramen för en sådan gemensam strategi bör det finnas utrymme för fasta samarbetsformer beträffande fackområdet PCB i byggnader.

\subsubsection{Krav på avfallsplaner}

Det finns en stor risk att PCB-produkter och som inte identifieras vid en miljöinventering i bästa fall hamnar på en kontrollerad deponi eller i en förbränningsanläggning och i värsta fall hamnar i naturen vid okontrollerad deponering.

Idag har inte alla de nordiska länderna och kommunerna krav på att fastighetsägaren genomför en miljökartläggning och upprättar en «avfallsplan» före rivning eller ombyggnad. Alla de nordiska länderna borde 
ha krav på sådana avfallsplaner. Först då kan man börja få kontroll på avfallsmängderna, hur avfallet hanteras och vart det tar vägen.

\subsubsection{Viktiga arbetsuppgifter för de centrala myndigheterna}

Gemensam nordisk tolkning av EU: s direktiv om PCB

De nordiska länderna borde ha en gemensam syn på hur EU: s direktiv om PCB ska tolkas och tillämpas.

Anpassning av regelverket

Mot bakgrund av att man i de nordiska länderna använder olika sätt att ange PCB-halterna - total PCB respektive Sum7PCB - föreslås att man etablerar ett gemensamt nordiskt sätt att ange PCB-halten. Detta får t.ex. stor betydelse för tillämpningen av gränsvärdet $50 \mathrm{mg} / \mathrm{kg}$ (50 ppm). Se avsnitt 3.8.1.

Det är också angeläget att utveckla en gemensam nordisk syn på hur det byggavfall som ligger under $50 \mathrm{mg} / \mathrm{kg}$ får användas. Det bör t.ex. noteras att riktvärdet för känslig markanvändning i Norge ligger på 0,01 $\mathrm{mg} / \mathrm{kg}$.

I de nordiska länderna, i synnerhet i de nordliga delarna av Norge, Sverige och Finland samt på Island är bebyggelsen gles och kommunerna små. I sådana områden är det svårt att bygga upp tillräcklig kompetens och tillräckliga resureser. Men även här måste man kunna hatera PCBproblemet vilket ställer krav på att lagar och förordningar utformas så att de kan fungera för såväl stora som små projekt.

\section{Tillsynsvägledning}

En av fackmyndigheternas viktigaste uppgifter är att tillhandahålla tillsynsvägledning till tillsynsmyndigheterna (om blant annet regelverk, saksbehandling og gjennomføring av tilsyn). Länderna skulle kunna spara resurser genom att ta fram gemensamma tillsynsvägledningar.

Information om PCB och saneringsåtgärder

En annan viktig uppgift för fackmyndigheterna är att ta fram lättillgänglig och väl strukturerad information om den mest utvecklade kunskapen och pågående projekt beträffande PCB i byggnader. Några exempel på rubriker: arbetsmetoder för sanering, arbetsmiljö, system för omhändertagande, lagkrav i de olika länderna, utarbetat informationsmaterial osv. Informationen skulle t.ex. kunna vara tillgänglig i form av en gemensam webbplats, där varje land löpande kan lägga in aktuell information.

Önskvärt vore att det i t.ex. Nordiska rådets regi genomförs återkommande nordiska seminarier för att underlätta erfarenhetsutbytet. 


\subsection{Tillsynsmyndigheter}

\subsubsection{Förbättra tillsynen}

Ett regelverk fungerar inte utan uppföljning och kontroll. Det är vanligt att man ställer krav på miljöinventering och avfallsplaner utan att det följs upp med vägledning och kontroll från tillsynsmyndigheten. Länderna måste därför satsa på att höja kompetensen beträffande PCB och andra miljöstörande ämnen hos tillsynsmyndigheten och ge den tillräckliga resuser för att följa upp och kontrollera att regelverket efterlevs.

Tillsynsmyndigheterna är viktiga rådgivare och samarbetspartners för mindre företag med låg egen kompetens inom miljöområdet.

\subsection{Miljökonsulter}

\subsubsection{Höj kvaliteten på miljöinventeringarna}

Ett viktigt uppgift är att höja kvaliteten på miljöinventeringarna så att PCB blir kartlagt och hanteras på rätt sätt - utan att belasta miljön. Kvaliteten på miljöinventeringarna är emellertid ojämn och det är svårt för en fastighetsägare att bedöma kompetensen hos en miljöinventare. I Sverige finns en utbildning och en CMF-standard for miljöinventerare. I Norge finns det kurser och vägledningar men inga formella krav. Den svenska modellen skulle kunna vara utgångspunkten för en nordisk modell för kvalitetssäkring av miljöinventerare. Miljöinventering skulle med hjälp av ett sådant förfaringssätt kunna få en formell yrkesmässig status.

\subsection{Fastighetsägare}

\subsubsection{Kartlägg PCB och förbered för sanering}

Fastighetsägarnas viktigaste uppgift i det här sammanhanget är att förbereda sig väl för saneringsarbetet genom att i god tid inventera PCB och lägga in saneringsarbetet i sin långsiktiga planering.

En annan viktig uppgift är att vid upphandling av konsulter och saneringsföretag försäkra sig om att de företag man anlitar har tillräcklig kompetens. 


\subsection{Saneringsföretag och deras organisationer}

\subsubsection{Utbilda personalen!}

Saneringsföretagets viktigaste uppgift är här att tillse att den personal som utför saneringarna har tillräcklig kompetens.

\subsubsection{Kvalitetssäkra saneringsarbetet}

För många fastighetsägare är det svårt att bedöma kvaliteten på de företag som lämnar pris på en sanering. Det hade varit önskvärt att det fanns en kvalitetssäkring - certifiering eller auktorisation för de företag och personer som utför saneringar. Detta skulle skapa bättre konkurrensförhållanden och underlätta för seriösa företag att konkurrera med de oseriösa.

En certifiering eller auktorisation skulle kunna skapas på en nordisk nivå. En personcertifiering skulle kunna ge PCB-sanering en formell yrkesmässig status.

\subsection{Aktiviteter inom forskning och utveckling}

\subsubsection{Behov av ny kunskap}

Mer forskning och utveckling är av värde för att belysa problemen, och den nya kunskapen kan ge tyngd åt argumenten för åtgärder. FoU är önskvärt t.ex. för att öka kunskapen om :

- Hälsopåverkan från olika typer av PCB: er

- Miljöpåverkan av kontaminerade material som återvinns t.ex. som fyllnadsmassor

- Spridning av PCB från PCB-haltiga produkter till andra material, t.ex. via luften

- Kartläggning av olika användningsområden för PCB, vilka mängder som använts, vilka mängder som återstår samt vart resten tagit vägen

- Kartläggning av hur PCB har använts i putsbruk

- Kartläggning av hur PCB har använts i färger

\subsubsection{Behov av teknisk utveckling}

Det finns behov av teknisk utveckling när det gäller t.ex.

- Saneringsutrustning

- Ergonomiskt utformade verktyg t.ex. avlastande hjälpmedel för handhållna verktyg

- Sanering av PCB-fogar utan handhållna verktyg 
- Kostnadseffektiva metoder för PCB-sanering

- Metoder för sanering av färger och putsbruk som innehåller PCB

- Sanering av PCB-förorenade markområden

\subsubsection{Samordna FoU-arbetet i de nordiska länderna}

Idag bedrivs mycket arbete parallellt i de nordiska länderna. Genom att samordna resurserna tvärs över landsgränserna skulle man kunna påskynda FoU-arbetet.

\subsection{Byggutbildningarna}

Kunskaperna om PCB och andra miljöstörande ämnen måste överföras till byggutbildningarna. 


\section{Summary}

PCB contamination in buildings is a problem worldwide, however the extent and nature of the contamination varies. PCB is an environmental pollutant which accumulates throughout the food chain, thus introducing itself as a potential health hazard for both humans and animals. From the 1950 's to 1980, PCB was widely used in various building related materials and technical installations. A large number of these buildings or installations are now in a state requiring demolition or modernisation. In buildings, one might expect PCB to be present in sealants, floorings, paints, mortar, double-glazed windows, capacitors in light fittings, other small capacitors and cable outlets in power supply units.

The Nordic countries have handled the PCB-matter in different ways and to different extents. Sweden has focused on the mapping and removal of sealants within a given deadline, establishing guidelines on the safe removal of these sealants. Norway has focused on double-glazed windows and capacitors in light fittings, and has established recycling programs, financed through the purchase of new products. Norway also maps out the PCB-content in paints and mortar, and has established guidelines on the safe removal of such materials. Like Sweden, Finland has focused on sealants, although paint has also been a focus area as of late. So far, Denmark has focused on the successful recycling of material/waste from demolished/restored buildings, rather than focusing on hazardous components in the waste. Iceland has not focused on PCB in buildings, with the exception of PCB-containing oil in technical installations. The common denominator linking Norway and Sweden is the increased focus on working environment during the removal of PCB in buildings. Norway, Sweden and Finland have all carried out surveys in order to determine the leaching of PCB to the soil surrounding buildings.

The project "Riving og PCB $i$ bygg" is a combined Nordic project. Through cooperation among the Nordic countries, valuable sharing of knowledge and experience has been gained. The project has aimed at being solution orientated, ensuring the results of the project being suggestions which should be readily implemented by both the authorities, and the contracting business within the Nordic countries.

The seminar and the succeeding dialogue between the countries during the creation of this report have resulted in a number of suggestions on how to further handle PCB in buildings. The authors of the report have decided to aim the suggestions to the various actors within the different areas of the handling of PCB in buildings. 
Governments and central authorities

- Develop a common, Nordic understanding on PCB in buildings - both as an environmental and a health related concern.

- Develop a common, Nordic strategy for the handling of PCB in buildings and demolition waste - PCB must be treated in an environmentally safe manner during demolition and rehabilitation.

This could in practice involve:

- Demolition and rehabilitation must require waste management plans to be worked out according to specifications.

- A common, Nordic interpretation of the EU directive concerning PCB.

- Adjustment of the regulations through clear guidelines on surveying, handling and control with the removal and handling of PCBcontaminated waste. The guidelines must be formed in a manner that leads them to be fully understood and utilised in both large and small scale projects.

- Common guidelines for the supervising authorities (regarding regulations, procedures and inspections).

- Information on PCB, e.g. through a common website, where each country may add information on a regular basis.

- Repeated Nordic seminars and professional cooperation professional cooperation

Supervising authorities

- Improve supervision - competence and resources are prerequisites.

Consultants/advisors

- Improve the quality on hazardous material inventories, e.g. through authorisation/certification of the surveyors.

Builders

- Carry out PCB surveys, plan prior to PCB removal and carry out the planned removal rehabilitation.

- Ask for the relevant competence for both the environmental surveyors and the business carrying out the PCB-removal/demolition work.

Demolition/rehabilitation businesses and their organisations

- Educate personnel

- Perform quality surveillance on the work

- Authorisation/certification of the demolition/sanitation crew 
Research and development businesses

- $\mathrm{R} \& \mathrm{D}$ to increase the knowledge on both health and environmental effects of exposure to PCB, dispersion of PCB, increased mapping of how PCB has been utilised.

- Technical development regarding safety equipment, ergonomically better working operations for the removal of sealants, methods for rehabilitation/removal of paints, mortar and soil.

- Coordinate R\&D within the Nordic countries.

Educational institutions within civil engineering

- Gain knowledge on PCB

- Communicate knowledge regarding PCB through education

The most important priority for all actors is to ensure that PCB is surveyed/ researched to such an extent that PCB does not end up in nature, but is removed and handled in a safe manner, both with regard to health and environment. 



\section{Litteraturliste}

\section{Sverige}

1. Bernes C: Organiska miljögifter. Ett svenskt perspektiv på ett internationellt problem. Naturvårdsverkets förlag, 1998.

2. Miljöbalk (1988:808)

3. Plan- och bygglag (1987:10)

4. Arbetsmiljölag (1977:1160)

5. Förordning (1985:837) om PCB m $\mathrm{m}$,

6. Förordning (1998:122) om bortskaffande av PCB $\mathrm{m} \mathrm{m}$,

7. Förordning (2001:1063) Avfallsförordning

8. Förordning (2005:209) om producentansvar för elektriska och elektroniska produkter

9. Förordning (2002:1060) om avfallsförbränning

10. Förordning (2001:512) om deponering av avfall

11. Naturvårdsverkets föreskrifter om deponering, kriterier och förfaranden för mottagning av avfall vid anläggningar för deponering av avfall (NFS 2004:10)

12. Hygieniska gränsvärden och åtgärder mot luftföroreningar (AFS 2005:17)

13. Statens Naturvårdsverks föreskrifter om transportdokument för transport av farligt avfall (SNFS 1997:4)

14. Föreskrifter om ändring av Statens räddningsverks föreskrifter (SRVFS 2004:14) om transport av farligt gods på väg och i terräng.

15. Förordning (1998:901) om verksamhetsutövarens egenkontroll

16. Golder Grundteknik: Miljöteknisk markundersökning avseende PCB i jord inom fastigheten Örtuglandet $\mathrm{i}$ Åkeshov, Stockholm. Miljöförvaltningen i Stockholm, 1998.

17. Golder Grundteknik: Miljöteknisk markundersökning avseende PCB i jord inom fastigheten Högsätra i Sätra, Stockholm. Miljöförvaltningen i Stockholm, 1998.

18. PCB i fogmassor - stort eller litet problem? Rapport 4697 Naturvårdverket, 1997.
19. Generella riktvärden för förorenad mark. Rapport 4638 Naturvårdsverket, 1996.

20. PCB i inomhusmiljön. Kartläggning av PCB-halter i inomhusluft och damm i utvalda lägenheter i

Stockholm. Miljöförvaltningen i Stockholm, Sveriges Provningsoch Forskningsinstitut, 2001. (Finns på www.slb.mf.stockholm.se/miljo/pcb/)

21. Utveckling og utvärdering av metoder för utbyte av PCB-haltiga fogmassor. SP-rapport 1999:07.

22. PCB i bygg fogar. Utveckling och värdering av metoder för sanering av PCB-haltiga fogar i byggnader. Svenska Fogbranschens Riksförbund, Svenska Byggbranschens Utvecklingsfond, SBUF, 1999.

23. Handledning för fogentreprenörer. Sanera PCB-haltiga fogmassor. SFR (1999), utg 5, januari 2005.

24. Spridning av PCB från fogmassor till angränsande material. Rivning och sanering vid rivning. FoUVäst 2002 Rapport 0202.

25. Spridning av PCB från fogmassor till angränsande material. Provtagningar, analyser och utvärdering. SP-rapport 2001:02.

26. Inventera och sanera PCB! Handbok för miljöanpassad hantering av PCB i byggnader. Utgåva 2 september 2002. Byggsektorns Kretsloppsråd - Projektet PCB i Byggnader.

27. Omhändertagande av PCB i byggnader, Redovisning av ett regeringsuppdrag Naturvårdsverket och Boverket, juni 2002.

28. Vägledning för kontroll av arbetsmiljön vid sanering av PCB-fogar under 2003, Arbetsmiljöverket 2003.

29. Demontering och hantering av isolerrutor med PCB. En information från Glasbransch-föreningen och Svensk Planglasförening, sept 2001. 
30. Stoppa PCB! En informationsskrift framtagen av Fragmenteringsbranschen och Renhållningsverksföreningen (RVF) med stöd från Naturvårdsverket, 2000.

31. Utveckling och utvärdering av metoder för utbyte av PCB-haltiga fogmassor. SP, Sveriges Provnings- och Forskningsinstitut, 1999.

32. Jansson Bo et al, Ogonmattet - a case study of emissions during replacement of PCB containing sealants. Institute of Applied Envri- onmental Research, Stockholm University, 2000.

33. Jensen, S., Johnels, A.G., Olsson, M., Otterlind, G. (1969). DDT and $\mathrm{PCB}$ in marine animals from Swedish waters. Nature, Vol. 224, pp. 247.

34. Hammar, T. (1992). PCB i fogmassor. Länsstyrelsen i Kalmar Län informerar 1992:10.

35. Swedish Environmental Protection Agency. (1998). Presistent organic pollutions: A Swedish view of an internaltional problem, text by Claes Bernes, Monitor 16.

\section{Norge}

36. Stortingsmelding nr. 21 (20042005) Regjeringens miljøvernpolitikk og rikets miljøtilstand, 18. mars 2005.

37. Stortingsmelding nr. 25 (20022003) Regjeringens miljøvernpolitikk og rikets miljøtilstand, 25. april 2004.

38. Stortingsmelding nr. 58 (19961997) Miljøvernpolitikk for en bærekraftig utvikling, 6. juni 1997.

39. Lov om forurensninger og om avfall av 13. mars $1981 \mathrm{nr}$. 6, (forurensningsloven).

40. Lov om kontroll med produkter og forbrukertjenester av 11. juni 1976 nr. 79 (produktkontrolloven).

41. Lov om arbeidsmiljø, arbeidstid og stillingsvern mv. av 17. juni 2005 nr. 609 (arbeidsmiljøloven)

42. Forskrift om gjenvinning og behandling av avfall (avfallsforskriften)

43. Forskrift om begrensning av forurensning (forurensningsforskriften)

44. Forskrift om begrensning i bruk av helse- og miljøfarlige kjemikalier og andre produkter (produktforskriften)

45. Identifisering av PCB i norske bygg. Veileder fra ØkoBygg, april 2002.

46. Veileder for miljøkartlegging av bygninger. RIF - Organisasjonen for rådgivere, 2004.

47. Veiledning om risikovurdering av forurenset grunn, SFT 99:01A, TA-1629

48. Miljøsaneringsveileder. Veileder i miljøsanering av bygninger. 3 . utgave. Norges Miljøvernforbund.

49. PCB i bygg. SFT faktaark $1730 / 2000$. Statens forurensningstilsyn, 2000.

50. Uttak og håndtering av eldre isolerruter. Informasjon til entreprenører. SFT faktaark 1731/2000. Statens forurensningstilsyn, 2000

51. Mottak av eldre isolerruter. Informasjon til avfallsmottak. SFT faktaark 1732/2000. Statens forurensningstilsyn, 2000

52. Disponering av rene naturlige masser og gjenvunnet materiale. SFT faktaark 1853/2002. Statens forurensningstilsyn, 2000

53. PCB i bygningsmaterialer. SFTrapport nr 98:09. Statens forurensningstilsyn, 1997. ISBN-82-7655111-4.

54. Trygg disponering av rive- og anleggsmasser. Utarbeidet av Norges geologiske undersøkelse for SFT, 2002.

55. PCB i yttervegger i hus fra Bergen og uteområdene rundt bygningene. NGU-apport 2002.102. Utarbeidet av Norges geologiske undersøkelse for Bergen kommune, 2002.

56. PCB i yttervegger i hus fra Tromsø. NGU-rapport 2002.103. Utarbeidet av Norges geologiske undersøkelse for Tromsø kommune, 2002.

57. Prøvetaking og analyse av PCB i betong. Kartlegging av metoder. DNV-rapport nr 98-3545 finansiert av ØkoBygg, Det Norske Veritas, 1998.

58. Veileder for bruk av resirkulert tilslag. RESIBA/ØkoBygg, 2002. 
59. Miljøpåvirkning ved bruk av resirkulert tilslag. RESIBA Prosjektrapport 03/2002, NBI Prosjektrapport nr. 333, Byggforsk, 2002.

60. Forslag til deklarasjonsordning for resirkulert tilslag. RESIBA Pro-

\section{Danmark}

62. Ahlborg, U., Hanberg, A., Kenne, K. (1992). Risk Assessment of Polychlorinated Biphenyls (PCB). Nord 26. Nordic Council of Ministers, Copenhagen.

63. Arbejdstilsynet. (2005). Grænseværdier for stoffer og materialer (At-vejledning C.O.1).

64. Demex, By og Byg, COWI, Teknologisk Institut. (2001). Andre problematiske stoffer i bygge- og anlægsaffald.- Kortlægning og prognose for affaldsstrømme samt undersøgelse af bortskaffelsesmuligheder. FASE I Miljøministeriet Miljøstyrelsen. Under udarbejdelse.

65. Fugebranchens Samarbejs- og oplysningsråd (FSO). (2000). Spørgeskemaundersøgelse om anvendelse af fugemasser med PCB.

66. Fødevaredirektoratet. (1999). Overvågningsrapporten 1994-1996 (Se www.fdir/publikationer/publikationer/publikationer/ovevaagningsrapport)

67. Hansen, E. og Grove A. COWI. (1983). PCB/PCT-forurening - En sjektrapport 04/2002, NBI Prosjektrapport nr. 328, Byggforsk, 2002.

61. Administrative normer for forurensning i arbeidsatmosfære 2001. Arbeidstilsynet (best.nr. 361)

udredning om forbrug, forurening og transportveje for PCB og PCT i Danmark. COWIconsult for Miljøstyrelsen, september 1983, ikke publiceret.

68. Hamberg, A., Olsen, F. B. (1970). Vægkonstruktioner. DIAB Husbygning. Den private ingeniørfond. Danmarks Tekniske Højskole.

69. Nissen, H. (1984). Montagebyggeri. Polyteknisk Forlag.

70. Nørhede, P and Larsen, J.C. (2003). Evaluation of health hazards by exposure to PCDDs, PCDFs and dioxin-like PCBs. Institut for Fødevaresikkerhed og Ernæring, Fødevaredirektoratet. Baggrundsrapport udarbejdet for Miljøstyrelsen.

71. Sundhedsstyrelsen. (1999). Indhold af dioxiner, $\mathrm{PCB}$, visse chlorholdige pesticider, kviksølv og selen i modermælk hos danske kvinder 1993-94.

72. Sundhedsstyrelsen.Krogh H. 1999. Problematiske stoffer i byggevarer. SBI-meddelelse 122. Statens Byggeforskningsinstitut.

\section{Finland}

73. Miljöskyddslag $86 / 2000$

74. Miljöskyddsordning 169/2000

75. Avfallslag 1072/1993

76. Avfallsordning 1390/1993

77. Miljöministeriets förordning om en förteckning över de vanligaste typerna av avfall och över problemavfall (1129/2001)

78. Statsrådets beslut om tagande ur bruk av PCB och PCB-utrustning samt behandling av PCB-avfall (711/1998)

79. Hellman, S. et. al., 2003, Elementtitalojen piha-alueiden PCB Tutkimukset, riskinarviointi ja riskinhallinta, Pirkanmaan ympäristökeskus (i finska)
80. Hellman, S., 2000, PCB-yhdisteet piha-alueen maaperässä - maaperän PCB-pitoisuuksien, aiheutuvan terveysriskin ja alueen kunnostusvaihtoehtojen tarkastelu, Pirkanmaan ympäristökeskus (i finska)

81. Kauranen, H. 2001, Demolition Techniques of block of flats. Rakennusteollisuuden Keskusliitto, RTK; RTK-Fakta Oy, Helsinki. 40 s. + liitt. 10 s. RTK Fakta, Kehitys \& Tuottavuus: 77 (i finska)

82. Maijala, J-P., Nippala, E., 2002, Elohopea ja PCB Suomen rakennuskannassa, Tampereen teknillinen yliopisto, Rakentamistalouden laitos (i finska) 
83. PCB i byggnader - PCBföreningar i fogmassor i elementhus, 2004, Mil-jöministeriet, $6 \mathrm{~s}+$ 2 tillläggblad.

84. PCB-kommissionens betänkande, 1983, Kommittébetänkande 1983:47, Valtion painatuskeskus, 188 s. (i finska)

85. Pentti, M., Haukijärvi, M., 2000, Rakennusten saumausmassat ja PCB-yhdisteet, Tampereen teknillinen yliopisto, Talonrakennustekniikka (i finska)

86. Pyy V., Lyly O., 1998, PCB elementtitalojen saumausmassoissa ja

\section{Andre land}

89. Polychlorinated biphenyls: human health aspects. Concise International Chemical Assessment Document 55. WHO, 2003.

90. Environmental Health Criteria 140. (1993). Polychlorinated Biphenyls and Terphenyls (second edition). International Programme in Chemical Safety (IPCS). World Health Organization. Geneva.

91. European Environment Agency. (2001). Late lessons from early warnings: the precautionary principle 1896-2000, Environmental issue, Report No 22 Edited by: Poul Harremoës (Chairman), David Gee (EEA editor), Malcolm MacGarvin (Executive editor), Andy Stirling, Jane Keys, Brian Wynne, Sofia Guedes Vaz. Published by Office for official publications of the european communities, Copenhagen.

92. Health Concerns about Environmental Polychlorinated Biphenyls (PCBs) (1997). Ecotoxicology and Environmental Safety 38 p 71-84.

93. Gabrio, T. et al. (2000). PCBblood levels in teachers, working $\mathrm{i}$ PCB-contaminated schools. Chemosphere 40 p.1055-1062.

94. Kimburgh, R.D. et al. (1987) Human health effects of polychlorinated biphenyls (PCBs) and Polybrominated biphenyls (PBBs). Ann. Rev. Phamacol. Toxicol., Vol. 27, pp. 87-111.

95. Mayes, B. A., McConnell, E. E., Neal, B. H., Brunner, M. J., Hamilton, S. B., Sullivan, T. M., Peters, A. C., Ryan, M. J., Toft, J. D., pihojen maaperässä, Helsingin kaupungin ympäristökeskus (i finska)

87. Rantio T. et. al., 2001, PCB- ja lyijypitoisten saumausmassojen poistaminen elementtirakennuksista, Tampereen aluetyöterveyslaitos (i finska)

88. Rivning av PCB- och blyhaltiga elementfogar RATU 82-0238 (publicerad i finska), 2000, Rakennusteollisuuden Keskusliitto r.y., Rakennustietosäätiö, Rakennustieto Oy, 6 s. (i finska)

Singer, A. W., Brown, J. F., Jr., Menton, R. G., and Moore, J. A. (1998). Comparative carcinogenicity in Sprague-Dawley rats of the polychlorinated biphenyl mixtures Aroclors 1016, 1242, 1254, and 1260. Toxicol. Sci. 41, 62-76.

96. Rice DC. (1999). Behavioral impairment produced by low-level postnatal PCB exposure in monkeys. Environ. Res. 80, S113S121, 1999b.

97. SCF (Scientific Committee on Food). (2000). Opinion on the Risk Assessment of Dioxins and Dioxin-like PCBs in Food (Adopted on 22 November 2000) http://europa.eu.int/comm/food/fs/ sc/scf/out78_en.pdf

98. SCF (Scientific Committee on Food). (2001). Opinion on the risk assessment of dioxins and dioxinslike PCBs in food (update based on the new scientific information available since the adoption of the SCF opinion of 22 November 2000) (adopted by the SCF on 30 May 2001) http://europa.eu.int/comm/food/fs/ sc/scf/out90_en.pdf

99. Driker, C.K. et al. (1973). The problem of possible systemic effects from certain chlorinated hydrocarbons. Journal of Industrial Hygiene and Toxicology, Vol. 19, pp. 283-311.

100. Arnold D.L., Bryce F., Mes J., Tryphonas H., Hayward S., Malcolm S. (1999) Toxicological consequences of feeding PCB congeners to infant rhesus (Macaca mu- 
latta) and cynomolgus (Macaca fascicularis) monkeys. Food Chem. Toxicol. 37, 153-167.

101. ATSDR (2000). Toxicological Profile for Polychlorinated Biphenyls (Update). U.S. Department of Health \& Human Services, Public Health Service, Agency for Toxic Substances and Disease Registry.

Balfanz E., Fuchs J. and Kieper H. (1993) Sampling and analysis of polychlorinated biphenyls (PCB) in indoor air due to permanently elastic sealants. Chemosphere, 26:871-880.

103. Benthe, C., Heinzow, B., Jessen, H., Mohr, S., Rotard, W. (1992). polychlorinated biphenyls. Indoor air contamination due to Thiokolrubber sealants in an office building. Chemosphere 25, pp. 14811486.

104. Gabrio T., Piechotowski I., Wallenhorst T., Klett M., Cott L., Friebel P., Link B. and Schwenk M. (2000) PCB-blood levels in teachers, working in PCBcontaminated schools. Chemosphere 40: 1055-1062.

105. Jacobson, J.L., Jacobson, S.W., Humphrey H.E.B. (1990a). Effects of in utero exposure to polychlorinated biphenyls and related contaminants on cognitive functioning in young children. J. Pediatr 116, pp. 38-45.

106. Jacobson, J.L., Jacobson, S.W., Humphrey H.E.B. (1990b). Effects of exposure to PCBs and related contaminants on growth and activity in children. Neurotoxicol Teratol 12, pp. 319-326.

107. PCB-Belastung in Gebäuden. Erkännen - Bewerten - Sanieren. Wiesbaden, Berlin. Bauverlag $\mathrm{GmbH}$. Katalyse e. V., Institut für angewandte Umweltforschung, 1995. ISBN 3-7625-3243-5.

108. Stoffmonographie PCB - Referenzwerte für Blut. Bundesgesundheitsblatt - Gesundheitsforschung - Gesundheitsschutz. Institut für Wasser-, Boden- und Lufthygiene des Umweltbundesamtes, Kommission "Human Biomonitoring" des Umweltbundesamtes. Springer Verlag. Berlin. 42: 511-21.

109. Zweiner, G. (1994). Polychlorierte biphenyle in Gebaude. Deutsches Arkitechtblatt, Ausgabe BadenWuerttemberg, Vol. 26, pp. 786-789.

110. Formme, H., et al. (1994). Polyclorierte Biphenyle (PCB) in fugendichtungsmassen von gebäuden bestandsaufnahme fur Berlin und neue innenraumqullen, Konferenz:Luftverunreinigung in innenraumen, s. 791-797, Mannheim. 


\section{Linker til internett}

\section{Sverige:}

www.sanerapcb.nu (Miljökonsultgruppen i Stockholm HB, PCB-informationsprojektet) www.naturvardsverket.se (Naturvårdsverket) www.cf.vgregion.se/miljo/miljosamverkan (Miljösamverkan Västra Götaland) www.sfr.nu (Svenska Fogbranschens Riksförbund)

\section{Norge:}

www.bnl.no (Byggenæringens Landsforening) www.sft.no (Statens forurensningstilsyn) www.pcb.no (Generell informasjonsside om PCB) www.byggemiljo.no (Byggenæringens miløsekretariat) www.rif.no (RIF - Organisasjonen for rådgivere) www.miljosanering.no (Referansesider for miljøsanering og selektiv riving) www.ruteretur.no (Returordningen for kasserte PCB-holdige isolerglassruter) www.kondensator.no (Informasjonsside fra RENAS om PCB-holdige kondensatorer) www.folkehelsa.no (Statens folkehelseinstitutt)

\section{Finland:}

www.miljo.fi (Statens miljöforvaltning, miljömyndigheternas hemsida) www.stm.fi/Resource.phx/sve/ansva/arbet/index.htx (Social- och hälsovårdsministeriet, Arbetarskyddavdelningen) www.ttl.fi/internet/svenska/ (Arbetshälsoinstitutet)

\section{Danmark:}

www.mst.dk (Miljøministeriet/Miljøstyrelsen) www.at.dk (Arbejdstilsynet) www.danskbyggeri.dk (Bygge- og anlægssektorens erhvervs- og arbejdsgiverorganisation) www.sbi.dk (Statens Byggeforskningsinstitut)

Island:

www.umhverfisraduneyti.is (Miljøministeriet) www.umhverfisstofa.is (Reykjavik Environmental Health and Protection Office) 